\title{
The sedimentology of Lower Palaeozoic black shales from the shallow wells Skelbro 1 and Billegrav 1, Bornholm, Denmark
}

\author{
GUNVER KRARUP PEDERSEN
}

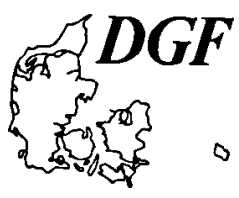

Pedersen, G.K.: The sedimentology of Lower Palaeozoic black shales from the shallow wells Skelbro 1 and Billegrav 1, Bornholm, Denmark. Bull. geol. Soc. Denmark, Vol. 37, pp. 151-173, Copenhagen, April 10th, 1989. https://doi.org/10.37570/bgsd-1988-37-13

Previous studies of the Lower Palaeozoic shales on Bomholm have mainly been based on the outcrops along the streams. The outcrops provide data on the lateral continuity of the facies while the selection of (2-3 cm wide) cores for the present study focused the attention on the vertical sequence of facies. Cores of high quality were obtained and have been found to provide an excellent basis for a study of structures, sediment composition and diagenesis. In the outcrops of shale fossils are locally present in high numbers and such levels are also recognized in the cores.

Seven sedimentary facies, ranging from black mudshale to greyish mudstone and silt-streaked shale, are distinguished in the Middle Cambrian to lowermost Silurian shales. Gamma-ray logs were run in the two wells and a convincing correlation to the cored sequence can be demonstrated. Gamma-ray logs provide thus a good means of correlation to wells where no cores have been cut. The shales are all interpreted as deposited in an epicontinental sea due to their geological setting i.e. the association with shallow water carbonates (Andrarum Limestone and KomstadLimestone) and their stratigraphical position above the shelf to shoreface sandstones of the Læså formation.

Three facies associations are distinguished: The mudshale association comprises black organic-rich shales which represent a low-energy anoxic depositional environment which prevailed in the Middle Cambrian to Lower Ordovician. The mudstone association is typical of the Middle and Upper Ordovician and represents a continuation of low-energy environments though mottling indicates that ventilation improved in certain periods. The siltshale association represents higher energy environments which were dominant in the lowermost Silurian.

A well defined Upper Ordovician CU sequence probably reflects the global eustatic fall in sea level caused by the extensive glaciation in Gondwanaland. In the late Silurian the average rate of deposition increased in response to the approaching Caledonian orogeny.

Pedersen, Gunver Krarup, Institut for almen Geologi, University of Copenhagen, Øster Voldgade 10, DK-1350 København K, Denmark. June 26th 1988.

\section{Introduction}

Outcrops of Lower Palaeozoic black shales are widely distributed in northwestern Europe and reviews have recently been given by Leggett (1980) and Thickpenny \& Leggett (1987). The uppermost Lower Cambrian to lowermost Silurian strata on Bornholm comprise grey to black marine mudrocks, with horizons of carbonate concretions, intercalated with few thin limestone units. The shales contain a marine fauna of trilobites, brachiopods and graptolites, unevenly distributed through the sequence (Figs 2, 3). Biostratigraphically it has been proven, that considerable hiati exist, especially in the Ordovician (cf. V. Poulsen 1966).

Previous work on the shale outcrops on Bornholm has been devoted mostly to the palaeontol- ogy and to a delineation of the numerous hiati characterizing the sequence. The stratigraphical framework was summarized by V.Poulsen (1966), Bjerreskov (1975), Surlyk (1980) and Bjerreskov \& Stouge (1985). Interest in the sedimentology and geochemistry was stimulated by the presence of uranium anomalies as well as oil shale properties in certain Upper Cambrian shales in Sweden (Bergstrøm \& Shaikh 1982, Andersson, Dahlman \& Gee 1983, Thickpenny 1984, Andersson et al. 1985). The hypothesis of oceanic anoxic events in the Cretaceous (Schlanger \& Jenkyns 1976, Fischer \& Arthur 1977, Demaison \& Moore 1980) reviewed the discussion of depositional models for the Lower Palaeozoic black shales (Berry \& Wilde 1978, Leggett 1980 , Leggett et al. 1981). Williams \& Rickards (1984) cautioned, however, against direct application of 


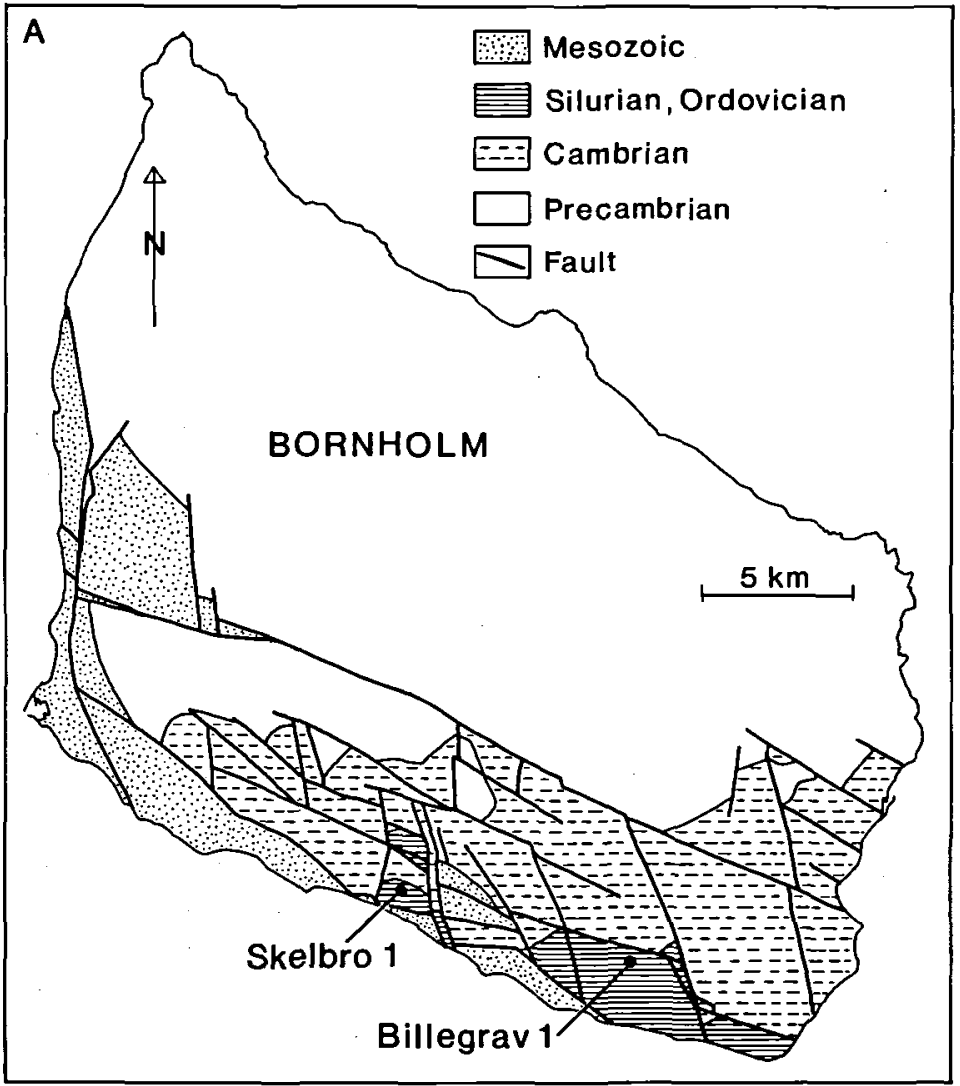

Fig. 1. (A) Simplified geological map of Bornholm showing the location of Skelbro 1 and Billegrav 1. Drawn from Gry (1977).

$(B, C)$ Location of the wells relative to the roads and the small streams $\emptyset$ le $\AA$, Laså and Risebak. (B) further locates the water-supply wells Sømarken 2 and Sømarken 3 . Sømarken 3 is identical with the Bavnegård well described by Bjerreskov (1975) and Poulsen (1978).

(D) shows the position of the island of Bornholm.
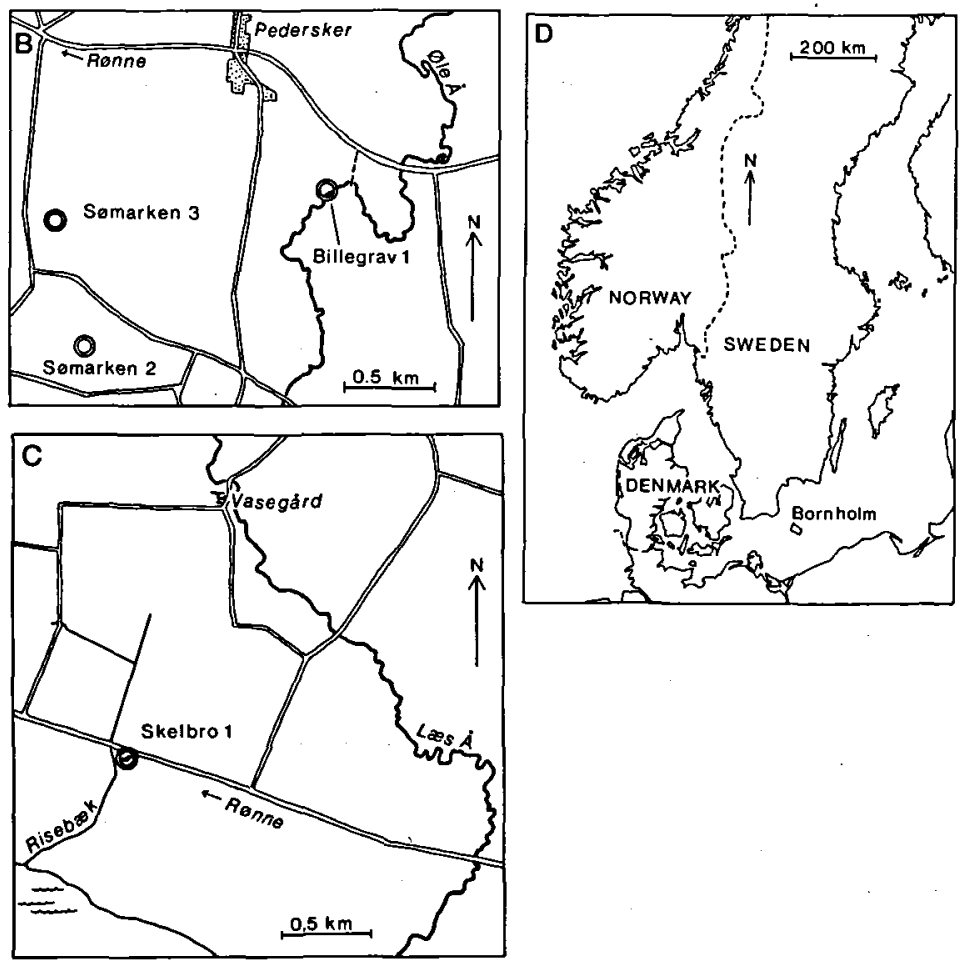
models developed for Mesozoic sediments to Lower Palaeozoic sequences. Recognition of anoxic depositional environments is based on observations of a preserved primary lamination, absence of trace fossils, lack of benthic fossils and the content of organic matter. Buchardt et al. (1985) pointed out, that all the organic matter preserved in the Cambro-Ordovician shales safely can be interpreted as marine due to the lack of a continental vegetation.

The aim of the present study has been to describe the sedimentary facies of the shales, the distribution of fossils and burrows within each facies and to discuss the depositional environment.

The Lower Palaeozoic shales on Bornholm are exposed in a number of small fault blocks, tilted at low angles, and are accessible along the streams Laså and Øleå in a number of small outcrops (Fig. 1). A record of sedimentary facies in these outcrops requires good palaeontological control, because minor faults may be passed unnoticed thus leading to gaps or repetitions in the sequence. The exposed shales are strongly fissile and are too indurated to be cut by knife, which makes it virtually impossible to obtain good samples from the outcrops. Cores were therefore selected as basis for this sedimentological study because they provide continuous, unweathered samples relatively little affected by fissility. Field observations of the shales in various outcrops indicate that the sedimentary facies are laterally continuous, and this is supported by petrophysical logs from various water supply wells (K.Klitten, pers.comm.). Therefore even a narrow vertical section (a core) can be considered representative of the sequence.

\section{Geological setting}

Bornholm is located within the Fennoscandian Border Zone and constituted a part of the relatively stable Balto-Scandian Precambrian platform until late Silurian times (Troedsson 1932, Pegrum 1984, Bjerreskov \& Stouge 1985, Vejbæk 1985). Two provenance areas can be suggested for the Lower Palaeozoic sediments on Bornholm. Rivers draining the Precambrian terrains of Sweden, Finland and the Soviet Union supplied sediments across the Balto-Scandian Plat- form into the Iapetus Ocean. With the onset of the Caledonian orogeny the relief increased and huge amounts of sediment accumulated in the Polish Trough (Bjerreskov \& Jørgensen 1983, Pegrum 1984). The Early Palaeozoic sedimentation style can be interpreted as recurring, probably tectonically caused deepenings and transgressions followed by coastline progradations and the very slow average rate of deposition corresponds well with the presence of numerous hiati (Surlyk 1980). C.Poulsen \& V.Poulsen (1979) concluded, that the Bornholm area must have been continental intermittently because the hiati have a duration which cannot easily be reconciled with periods of marine non-deposition. The major hiati are frequently accompanied by phosphorite cementation but there is no sedimentary evidence of subaerial exposure or of shallow-water wave-reworking.

The early Cambrian transgression is documented in the sedimentary sequence on Bornholm (Hansen 1937, Surlyk 1980). The Precambrian basement is overlain by the reddish feldspatic Neks $\emptyset$ Sandstone deposited by ephemeral stream and aeolian processes on a broad coastal floodplain (Dam \& Clemmensen 1988). The overlying shallow marine Balka Sandstone is a pale, quartz-cemented orthoquartzite, locally glauconitic, with sedimentary structures indicating tidal activity and abundant trace fossils ( $D i$ plocraterion, Skolithos and Planolites) (Clausen \& Vilhjálmsson 1986). A similar association of sedimentary facies characterizes the Hardeberga Sandstone of Scania (Hamberg 1988). Dott et al. (1986) discuss the likelyhood of Lower Cambrian well-sorted orthoquartzitic sandstones owing their petrographic characteristics to aeolian and fluvial processes but their final deposition and sedimentary structures to shallow marine environments. The overlying Læså formation (Surlyk 1980) constitutes an upwards coarsening sequence of dark green, glauconitic siltstone with numerous burrows produced by deposit feeders (Clausen \& Vilhjálmsson 1986). The association with thin storm layers indicate a transition from shelf, across lower shoreface into foreshore environments (the Rispebjerg Sandstone). The Læså formation was cored at $36.5-43 \mathrm{~m}$ in the Skelbro 1 well (Fig. 2).

Grey to black marine shales dominate the Middle Cambrian to lowermost Silurian sequence on 


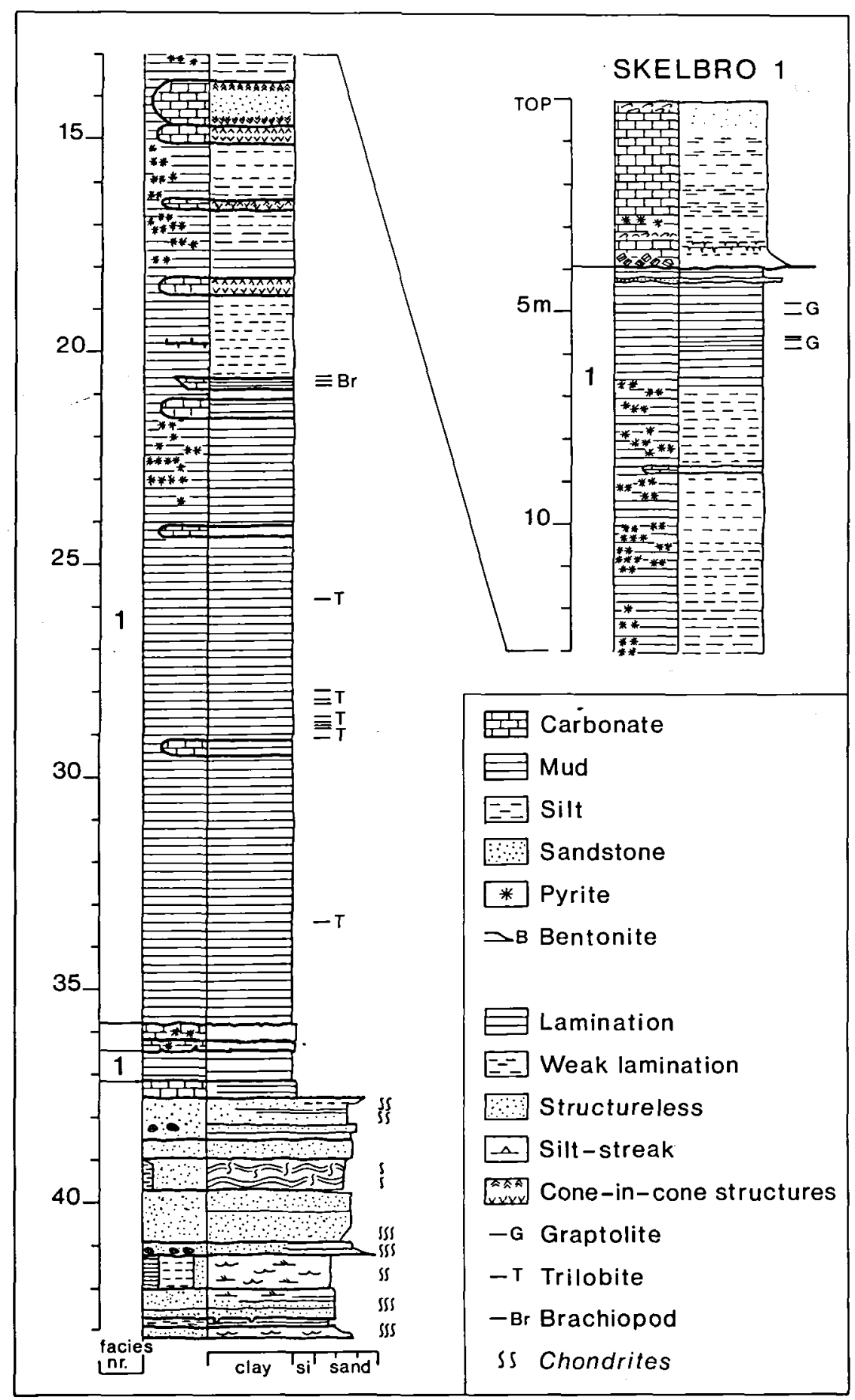

Fig. 2. Sedimentological log from the shallow well Skelbro 1 . The depths were measured below ground: $35 \mathrm{~m}$ above sea level. The sedimentary facies and the distribution of fossils is shown. Geochemical data are plotted in Fig. 11. 


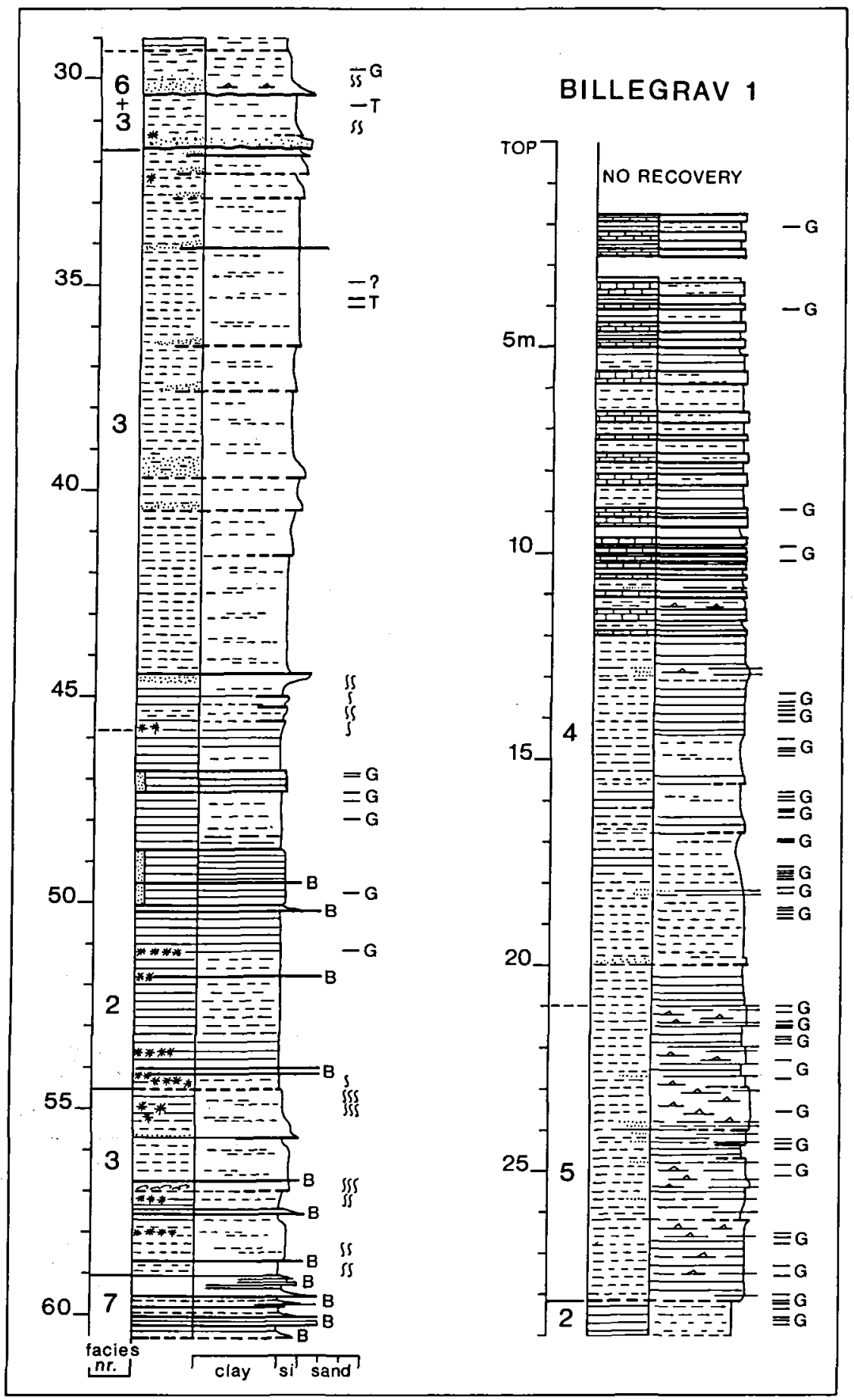

Fig. 3. Sedimentological log from the shallow well Billegrav 1. Depths were measured below ground: $15 \mathrm{~m}$ above sea level. The sedimentary facies and the distribution of fossils is shown. Geochemical data are plotted in Fig. 11. 
Bornholm (Figs 2, 3, 11). Deposition of dark grey graptolite shales continued and the preserved lower Silurian is $185 \mathrm{~m}$ thick on Bornholm (Bjerreskov 1975, Bjerreskov \& Jørgensen 1983). The equivalent and younger Silurian sediments in Scania reach thicknesses of $1-1.5 \mathrm{~km}$ and are preserved in tectonically controlled troughs (Bergström 1982). Seismic data indicate that the Silurian strata offshore Bornholm are up to $4 \mathrm{~km}$ thick (Vejbæk 1985).

\section{Material}

The present study is based on core material from two shallow wells, Skelbro 1 and Billegrav 1 (Figs $2,3)$. Skelbro 1 was drilled in the old limestone quarry at Skelbro (UTM coordinates VA923996) and Billegrav 1 is located in the Øleå-valley (UTM coordinates WA001971). Depths are given in metres below the ground and according to mapsheets 1812 III NV and 1812 III $\varsigma \varnothing$ from the Geodetic Institute the elevation at Skelbro is 35 $\mathrm{m}$, and $15 \mathrm{~m}$ at the site of Billegrav 1 . The wells were drilled in May 1984 with the purpose of providing material for the present study, namely a section of continuous cores from the upper Lower Cambrian into the lowermost Silurian strata. The drilling equipment and technical staff was kindly provided by the Geological Survey of Greenland. The work resulted in $100 \%$ recovery of $104 \mathrm{~m}$ of continuous, good quality cores $32 \mathrm{~mm}$ in diameter. Detailed sedimentological logs have been measured in the cores (Figs 2,3). The finegrained siliciclastic facies range from black organic-rich mudshale to greenish, bioturbated mudstone and pale grey siltshale. The terminology of Potter, Maynard \& Pryor (1980) is followed here. The presence of the primary lamination distinguishes mudshale from mudstone, while shale denotes the whole class of fine-grained siliciclastic sediments termed mudrock by Lundegard \& Samuels (1980). In the present material both mudshales and mudstones posses a diagenetic fissility and therefore "shale" is preferred instead of "mudrock". The colours describe dry samples because this gives the greatest range on the scale from grey to black. Described wet, most of the core material would be characterized as dark greyish green, dark grey or black.

Care has been taken to preserve the cores as unbroken as possible, and consequently a systematic search for fossils has been omitted. The fossils observed on chance bedding planes have been recorded on the sedimentological logs, but additional fossils very likely remain unnoticed in the cores.

\section{Sedimentary facies}

Facies 1: Black organic-rich mudshale

The mudshale is black, fine-grained and have average TOC values of $9 \%$ (Fig. 11). All the TOC determinations were carried out by $\mathrm{Bu}$ chardt et al. (1985) and Buchardt (unpublished data). Optical and pyrolysis analyses classify the organic matter as a type I kerogen, and microscopy shows a mixture of discrete algal bodies less than 10 microns in size, and lamellar and diffuse material intimately associated with the mineral matrix (Buchardt et al. 1985). The bulk mineralogy has been estimated from XRD-analyses, and the mudshale is found to contain $50-65 \%$ quartz, $5-15 \%$ feldspars and $10-15 \%$ muscovite (Fig. 11). Spears (1980) found that the quartz of shales mostly is of silt grade. The muscovite probably is both detrital and diagenetic in origin. The relatively high proportion of muscovite to quartz, coupled with the lack of coarse-grained silt or very fine-grained sand, suggests that the mud accumulated through slow settling of very fine particles from suspension. The black organic-rich mudshale generally has only a faint lamination but locally a distinct mm-scale lamination is seen. Erosive surfaces or graded laminae have not been observed. Trace fossils have not been observed and facies 1 is generally devoid of fossils. Olenid and agnostid trilobites, small brachiopods (Orusia sp.) or graptolites ("Dictyonema" now Rhabdinopora) occasionally are seen in high numbers on certain bedding planes within the cores (Fig. 2). Henningsmoen (1957) stated, that the olenids were especially adapted to a pelagic mode of life. Fortey (1974), however, argued that some olenids were adapted to a benthic life in a muddy substrate. C.Poulsen $(1922,1923)$ and Hansen (1945) noted that the Upper Alum Shale (part of facies 1) is characterized by thin, highly fossiliferous horizons separated by thicker sequences of barren shales. Within the fossiliferous horizons the fossils occur in abundance at the base and 


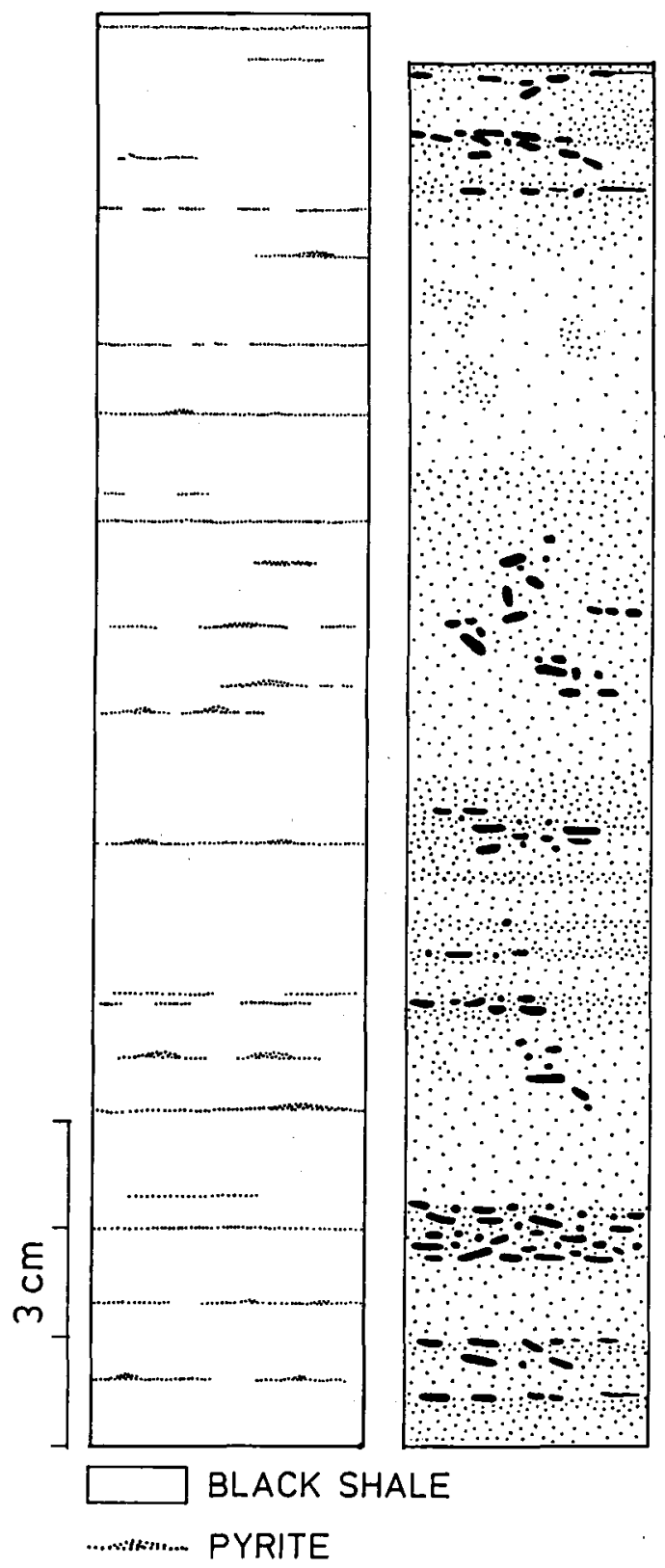

INDISTINCT LAMINATION

\section{₹:: CHONDRITES}

Fig. 4. Detail of the mudshale facies (A) in which the lamination is enhanced by very thin streaks of pyrite (Skelbro 1: 51 $\mathrm{m})$. (B) shows mudstone with indistinct lamination and uneven distribution of Chondrites (Billegrav 1: $30 \mathrm{~m}$ ).

decrease in number upwards (C.Poulsen 1922, 1923). Furthermore the olenids decrease systematically in width upwards through each fossilif- erous horizon (Kaufmann 1933a). This indicates that each fossiliferous horizon corresponds to a period of gradual impoverishment of the life conditions and suggests that the olenids were to some extent dependant on the substrate, as this was more likely to undergo environmental fluctuations than was the pelagic habitat.

The black mudshale has an average pyrite content of $11 \%$ (Fig. 11), most of which is finely disseminated. The macroscopic diagenetic pyrite varies in amount and mode of occurrence from very thin $(0.3-1 \mathrm{~mm})$ streaks or continuous laminae (Fig. 4(A)) to nodules $0.5-1 \mathrm{~cm}$ in diameter. The Upper Alum Shale is characterized by wedgeshaped pyritic pseudomorphs after baryte (Callisen 1914). These are concentrated in $1-2 \mathrm{~cm}$ thick beds which are separated by $15 \mathrm{~cm}$ black mudshale (Skelbro 1, 17.5-7 m). This distribution pattern of regularily spaced accumulations of wedgeshaped pyrites has not yet been explained.

Bituminous limestone concretions are a characteristic and generally subordinate component of the mudshale. The concretions are fine or coarse crystalline, massive or weakly laminated, and may show cone-in-cone structures at their rims. The concretions in Skelbro 1 are $20-100 \mathrm{~cm}$ thick and probably ellipsoidal like the corresponding concretions exposed along Læså (C.Poulsen 1923: fig. 2). Facies 1 corresponds typically to the Lower and Upper Alum Shale (Skelbro 1, 37-4 m) (Fig. 2).

Facies 1 is easily identified on the gamma-ray logs where exceptionally high average values are measured. Comparison between Figs 11 and 12 shows a distinct covariation between TOC and gamma-ray log values. In contrast the limestone beds and conglomerates show very low gamma-radiation.

Facies 1 is a marine deposit. The biostratigraphy indicates a very slow average sedimentation rate and thus ample time for degradation of organic matter or bioturbation of the sediment. The TOC values are very high compared to Mesozoic or younger anoxic marine sediments (Demaison \& Moore 1980). The organic matter is dominantly algal and thus highly susceptible to decomposition (Tissot \& Welte 1978). Its preservation therefore strongly indicates an anoxic depositional environment. The weak lamination, coupled with the absence of trace fossils, indicates a lack of benthos and is consistent with 
anoxic bottom water (Rhoads \& Morse 1971, Savrda et al. 1984). Such environments are often characterized by sediments with a distinct lamination on a mm-scale, provided the particles vary in composition or grain-size. The weak lamination seen in facies 1 is believed to reflect slow settling of homogeneous sediment. Kaufmann (1933b) suggested that the rate of deposition was lower on Bornholm than in Scania. Evidence of relatively rapid deposition of mud from density currents has not been found. Williams \& Rickards (1984) noted, in a study of graptolitic black shales, that the sediment was very soft during deposition and that a true sediment-water interface may have been lacking. I interprete the trilobite data as evidence for episodic oxygenation of the bottom water with establishment of a benthic fauna, which then gradually improverished due to a reversal to anoxic conditions. Bergström (1982) described the equivalent Swedish shales as dominated by olenid and agnostid trilobites and almost devoid of distinctly benthic faunas. Apparently there is no relationship between the distribution of fossils and the variations in pyrite or TOC in the Upper Alum Shale.

On basis of the type and amount of organic matter, the fossils and the preservation of a weak lamination facies 1 is interpreted as an anoxic hemipelagite. The variations in TOC can be traced laterally through gamma-ray logs run in water-supply wells and have thus stratigraphic significance locally (Fig. 12). Leggett (1980) suggested that the Lower Palaeozoic anoxic mudshales may represent deposition within the oxygen minimum zone, because their wide geographical extent cannot fit into a restricted basin model. The Scandinavian Alum Shale has been interpreted as a shelf deposit (Thickpenny 1984, 1987, Thickpenny \& Leggett 1987).

\section{Facies 2: Dark grey to black mudstone}

The dark grey to black structureless mudstone have TOC values of $3-5 \%$, significantly lower than in facies 1 , and higher contents of quartz (Fig. 11). Facies 2 is recognized on the gammaray $\log$ as a pattern of fluctuating but relatively high average values (Fig. 12). The mudstone often has a relatively well developed fissility. Gradual transitions exist between the mudshale of facies 1 and the black mudstone of facies 2 . Facies 2 contains a fauna of pelagic graptolites but distinct trace fossils which might have proven the existence of benthic organisms have not been observed. This composition of the fauna, combined with TOC values higher than in normal marine shales (Demaison \& Moore 1980), indicate an anoxic depositional environment for facies 2 , while the absence of lamination suggests bioturbation by a sparse benthic fauna, and thus a weakly or intermittently oxic environment. In the latter case the lack of trace fossils may reflect that the sediment had a soupy condition which was unfavourable for the preservation of trace fossils (Ekdale 1985). Good examples of facies 2 are seen in the upper part of the Dicellograptus Shale (Billegrav 1, 54.5-46 m). Leggett (1980) includes a facies similar to facies 2 in 'black shale'.

\section{Facies 3: Grey mudstone and siltstone}

Facies 3 comprises mudstone of varying pale to dark grey or greenish grey colours and with grainsizes ranging from clayey mudstone to siltstone containing some very fine-grained sand. TOC values of facies 3 averages $0-1 \%$ (Fig. 11), and this low organic content is reflected in the generally low gamma-radiation (Fig. 12). The mudstone contains locally $0-3 \%$ pyrite, concentrated in globular nodules $1-10 \mathrm{~mm}$ in diameter, while the thin pyrite streaks of facies 1 are absent. TOC values of facies 3 averages $0-1 \%$ (Fig. 11). Galleries of Chondrites alternate locally with weakly laminated sediment (Billegrav 1, 59-54 $\mathrm{m}$ and 46-44.5 m). Other trace fossils have not been recognized. Bromley \& Ekdale (1984) deduced that the Chondrites burrows were deep and reached down into slightly compacted sediments. Furthermore Chondrites was found to indicate anoxia which characteristically develop at depth in fine-grained sediments (Bromley \& Ekdale 1984). The alternation between weakly bioturbated sediment and levels with high densities of Chondrites might be analogous to the mud turbidites with sharp bases and bioturbated tops (Stow \& Piper 1984). Such graded mud beds may also be deposited from storm generated currents in shelf environments (Pedersen 1985). Examples of facies 3 are found in the lower Dicellograptus Shale (Billegrav 1, 59-54 m), in the Jerrestad Formation (Billegrav 1, 44.5-29.5 m) and locally in the Silurian shales. 

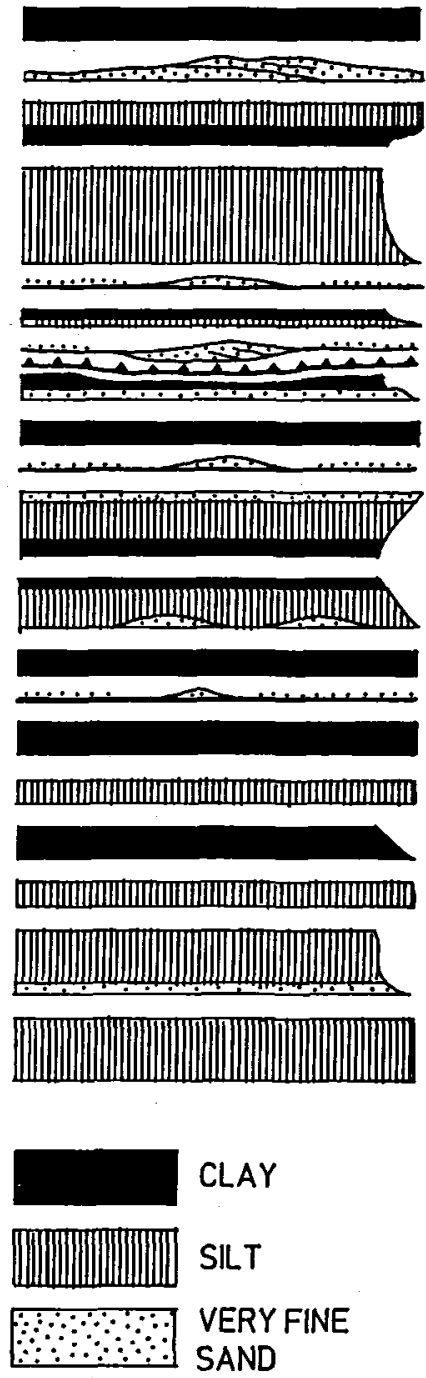
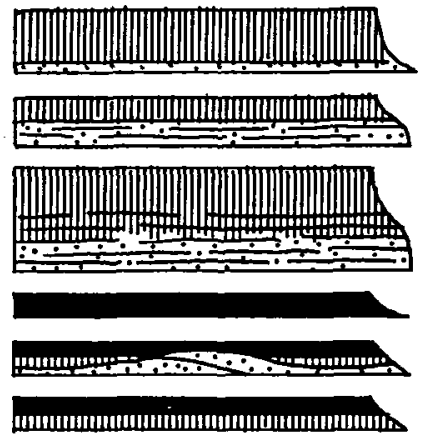

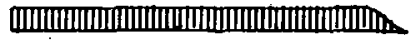
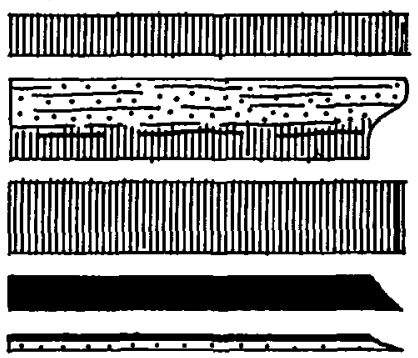

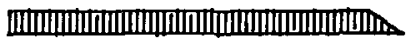

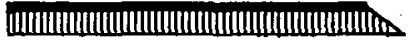
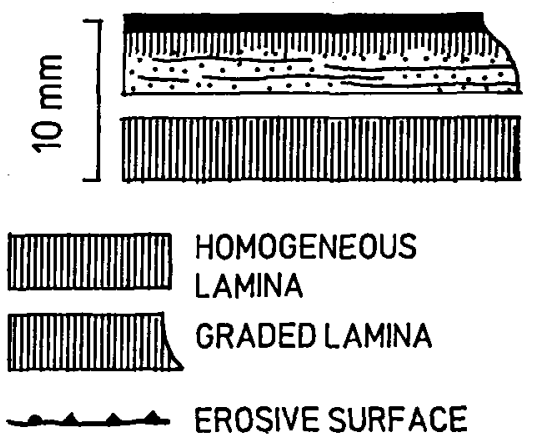

Fig. 5. Schematic drawing illustrating the range of grain-sizes and lamina thicknesses within the silt-streaked mudshale. Please note the random sequence of laminae.

On basis of the trace fossils, the grey colour and the low TOC values facies 3 is interpreted as a weakly oxic to normal marine shelf mud deposit.

\section{Facies 4: Grey siltshale}

The grey siltshale is characterized by $3-7 \mathrm{~mm}$ thick laminae which reflect subtle variations in grain size. It contains up to $3 \%$ pyrite and some organic matter (TOC $=0.5-2 \%$ ) (Fig. 11). Rare levels of bioturbation have been observed and only few, badly preserved fragments of graptolites are found locally. The silt-streaks characteristic of facies 5 are not seen in the siltshale. Locally the lamination is indistinct and, consequently, facies 4 approaches facies 3 . The siltshale is interbedded with $10-30 \mathrm{~cm}$ thick, carbonate-rich beds. Thin sections show that the carbonate mostly is present as blocky cement (Figs' 6A, 7C). On weathered surfaces, exposed along Øleå, the carbonate-cemented beds appear to be faintly laminated and coarser-grained than the surrounding siltshale. The preferential cementa- 

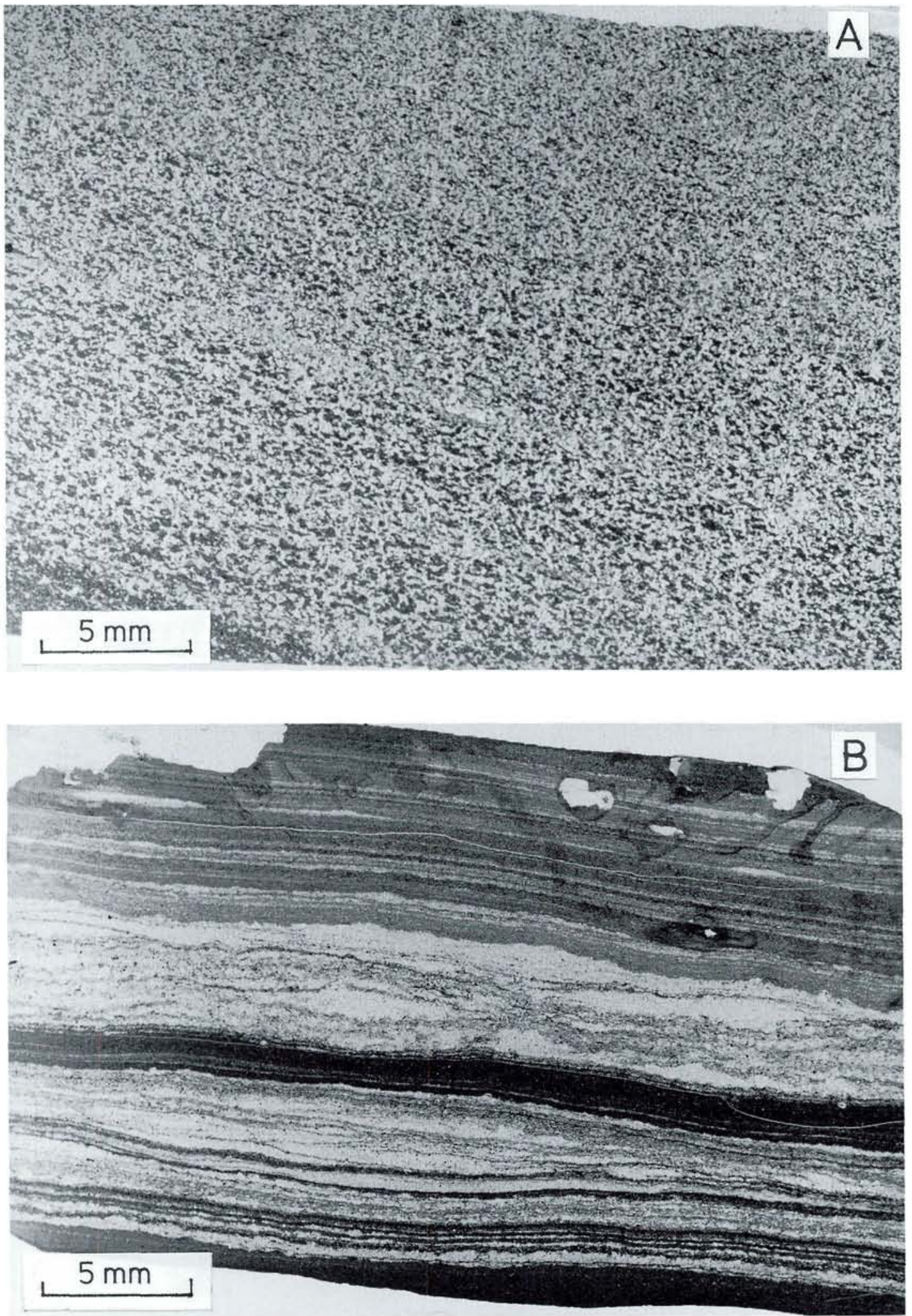


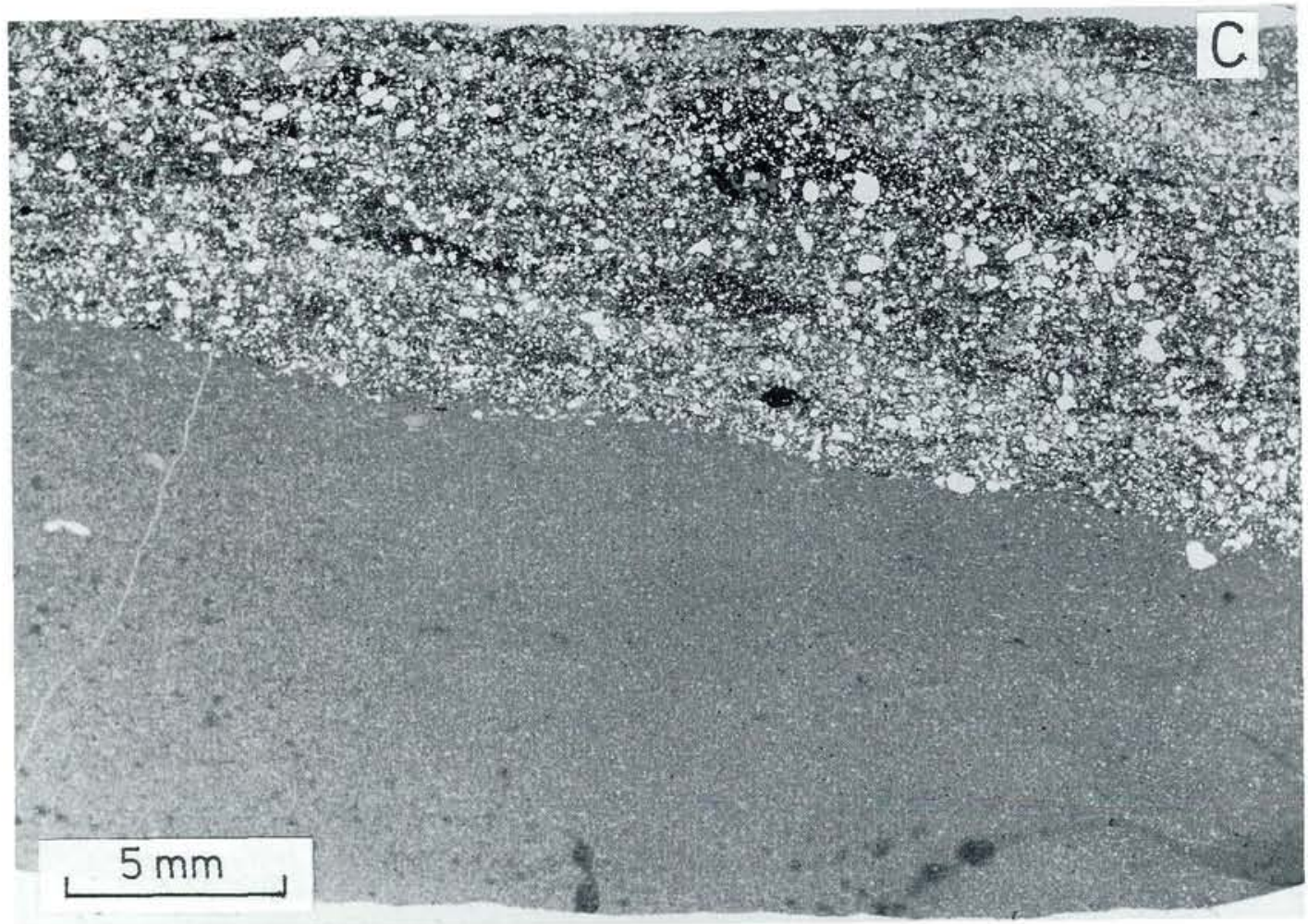

Fig. 6. Grey siltshale (facies 4) characterized by distinct laminae 3-7 m thick (Billegrav 1:23 m). Photomicrograph (A) of thin section from carbonate-cemented layer shows an indistinct lamination and the pale blocky cement. (B) Silt-streaked mudshale (facies 5) with pale laminae and cross-laminated ripples of silt in a matrix of dark grey mudshale. Photomicrograph of thin section. (C) Erosive bed of conglomeratic sandstone. The matrix supported conglomerate contain mudshale chips. Photomicrograph of thin section.

tion indicates higher initial permeability, probably caused by a greater particle size coupled with a winnowing of the fines. In Billegrav 1 $(0-11 \mathrm{~m})$ the carbonate-cemented beds are often structureless and have gradual transitions toward the siltshale. Normal grading or erosive bases have not been recognized in the core material.

The gamma-ray log show a gradual transition from facies 5 into facies 4 (Fig. 12: $21 \mathrm{~m}$ ). In contrast, the upper part of facies 4 is easily recognizable with low gamma-radiation corresponding to the low TOC and with strong fluctuations caused by the numerous carbonate-cemented beds (Figs 3, 12). Facies 4 is restricted to Billegrav $1(21-0 \mathrm{~m})$.

The $3-7 \mathrm{~mm}$ thick laminae are interpreted as being deposited rapidly from dense clouds of suspended material. The sedimentation probably was discontinuous and the laminae of the siltshale suggest a significantly higher rate of deposition than inferred for the mudshale.
Pedersen (1985) described a Lower Jurassic shelf sequence which includes a graded siltstone facies interpreted as fine-grained storm deposits. The grain-size variation across the graded beds is slight but is accompanied by winnowing of the clay in the basal parts of the beds and, consequently, the beds range in colour from pale at the bottom to dark at the top. A grading of this type might conceiveably be obscured by extensive cementation. Accordingly, the carbonate-cemented beds in the siltshale are interpreted as density flow deposits.

\section{Facies 5: Silt-streaked mudshale}

Facies 5 is characterized by the cm-scale alternation between dark grey mudshale and whitish streaks of coarse silt. The streaks are 1-5 mm thick, relatively well-sorted and have sharp bases. Normal grading is seen locally and the 


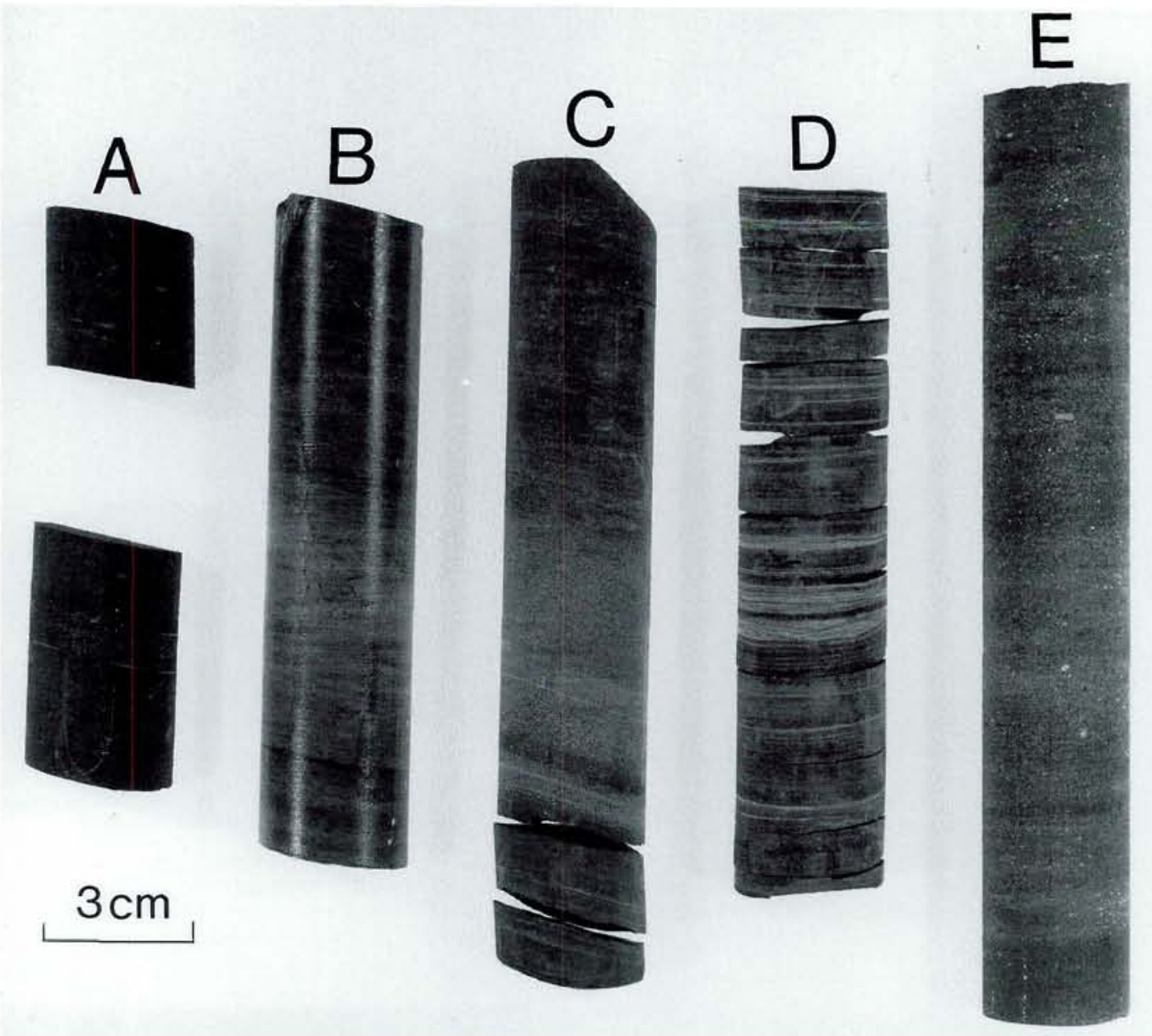

Fig. 7. Selected samples of the shale facies: A: black mudshale, B: grey mudstone with Chondrites burrows, C: grey siltshale with $8 \mathrm{~cm}$ thick, pale level with carbonate cementation, D: silt-streaked mudshale, E: conglomeratic sandstone.

silt-streaks vary from discontinuous laminae to diminutive cross-laminated ripples (Figs 5, 6B, 7D). The proportion of silt-streaks within the mudshale varies unsystematically every $10-20$ $\mathrm{cm}$. Note however, the slight upward decrease in the gamma-radiation which could reflect a decrease in either TOC or in the content of clay minerals. The TOC values are variable, $1-3 \%$ (Fig. 11) and the gamma-log motif (Fig. 12) may reflect an upward coarsening trend which is too faint to be observed in the core (Billegrav 1, 28-21 m). Facies 5 passes transitionally up into facies 4 (Figs 3,11). Trace fossils have not been observed, but a number of well-preserved graptolites are found. A preliminary examination of these refer them to the $G$. persculptus Zone of the latest Ordovician (M.Bjerreskov, pers.comm.).

The silt-streaked mudshale represents two depositional processes, namely a background sedimentation of mud punctuated by an episodic and more rapid deposition of the silt-streaks. The average grain-size, the sharp base, and the local normal grading, indicate that the coarse silt was deposited from density currents, while the crosslamination could be generated through reworking by traction currents. Similar facies have been reported from a storm-affected outer shelf environment (Pedersen 1985) and from fine-grained turbidites (Stow \& Shanmugam 1980) especially from top-cut-out sequences (Stow \& Piper 1984). Nelson (1982) commented on the similarity be- 


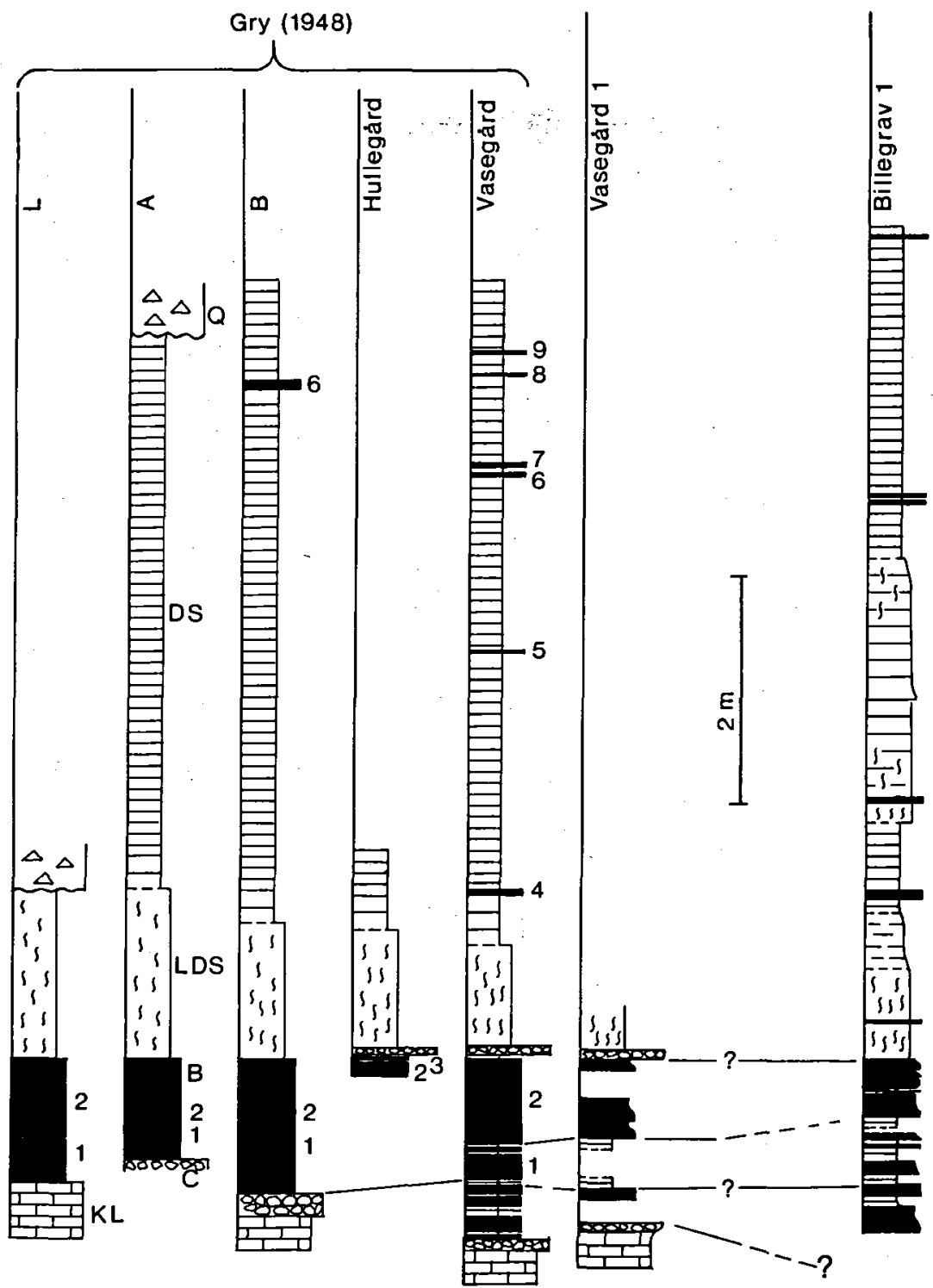

Fig. 8. Compilation of various profiles with thin bentonite layers and their correlation. All sections expect Billegrav 1 lie within $5 \mathrm{~km}^{2}$ and the bentonite beds vary thus rapidly in thickness. Note that the thickest bentonite (2) is composed of at least three normal graded beds in the core from Vasegård 1, but is seen as one bed in the nearby outcrop measured by Gry (1948). Five sections are drawn on basis of Gry (1948). His Vasegård section is based on Funkquist (1919) and is included in Bergström \& Nilsson (1974: fig. 1). The shallow well Vasegård 1 was drilled in 1982 and cored throughout. The log shows that recovery was incomplete in the bentonite section.

KL: Komstad Limestone, C: phosphoritic conglomerate, B: bentonite, LDS: lower part of Dicellograptus Shale which contain Chondrites burrows, DS: Dicellograptus Shale, Q: Quaternary.

tween storm sand layers and turbidites and storm-generated turbidites have been described by Benton \& Gray (1981) and Hamblin \& Walker (1979). Facies 5 is not exposed on Bornholm and its lateral distribution is therefore unknown.

\section{Facies 6: Conglomeratic sandstone}

Three beds of conglomeratic sandstone are seen in Billegrav $1(32-31 \mathrm{~m})$. The beds are $10-20 \mathrm{~cm}$ thick and comprise sand- to granule-sized clasts in a matrix of mud (Figs $6 \mathrm{C}, 7 \mathrm{E}$ ). The conglomerate beds have erosive bases, which locally are 
load-deformed. The clasts include chips of black shale as well as fragments of crystalline basement. The lateral extent and geometry of facies 6 is not known because outcrops are lacking.

The conglomerates are tentatively interpreted as thin debris flow deposits. Stratigraphically they are referred to the Upper Ordovician Tommarp Mudstone. V.Poulsen (1978) described the intercalated light grey, poorly fissile shales from the Bavnegaird well and referred them to the Dalmanitina Beds, which are considered to represent the regressive top of the Ordovician. A detailed correlation to the Swedish sequences is not possible (V.Poulsen 1978).

\section{Facies 7: Bentonite}

The existence of bentonite beds in the Dicellograptus Shale was established by Bøgvad (1946, 1947) and Gry (1948). Bergström \& Nilsson (1974) described a series of contemporaneous bentonite beds from southern Sweden and showed that the major pulses of tuff deposition can be traced from Sweden to Bornholm.

Some of the bentonite beds on Bornholm contain sand sized particles and may show normal grading. Gry (1948) described biotite and idiomorphic crystals of quartz, often with inclusions of devitrified volcanic glass, from the bentonites.

In Billegrav $1(61-50 \mathrm{~m})$ the bentonite beds occur as eighteen thin beds of yellowish green clay which differ markedly from the surrounding shales with respect to both colour and their relatively soft consistency. The beds range from $1 \mathrm{~cm}$ to at least $21 \mathrm{~cm}$ in thickness, their lower boundaries are sharp while the upper are gradational in some cases. The clay is dominated by mica (Fig. 11) but the strong asymmetry of the $10 \AA$ peak in the X-ray diffractogram indicates that the muscovite in part represents diagenetically altered smectite. Expandable clays have not been detected in the adjacent shales and indicate a different source of the greenish clay. Teale \& Spears (1986) reported interstratified illite-smectite from Silurian bentonites in Wales and suggested that possible sources for these ashes were Silurian volcanic centres in NE Sweden or Russia, while a trans-Atlantic correlation has been tentatively suggested by Bergström (1988). On the local scale a correlation is possible on basis of the gamma-ray $\log$, which shows a distinct peak where the bentonite beds are thickest and most closely spaced.

The volcanic ash settled below wave base and the resultant bentonite beds should be expected to be traceable over long distances. However, Gry (1948) noted that the basal bentonite layers at Vasegård are missing few kilometres away at Risebæk, and evidence of basinal redistribution of the ash is also discussed by Bergström \& Nilsson (1974). An explanation may be that the volcanic ash had a low density and settled slowly in patches of uneven thickness. Rapid lateral thickness variation in metabentonites is interpreted as indications of current activity and a possible irregular sea bed during deposition of graptolitic black shales which lack current-generated sedimentary features (William \& Rickards 1984). A correlation between the bentonite beds in Billegrav 1 and the bentonite beds in the Vasegard profile is shown in Fig. 8. Gamma-log correlation to Sømarken 2 indicates that c. $6 \mathrm{~m}$ of the Dicellograptus Shale was not penetrated in Billegrav 1 (Fig. 12).

\section{Diagenesis}

The Lower Palaeozoic sediments on Bornholm underwent deep burial diagenesis related to the accumulation of c. $4 \mathrm{~km}$ of upper Silurian sediments (Vejbæk 1985). Diagenetic temperatures in excess of $90^{\circ} \mathrm{C}$ have been estimated from carbon and oxygen isotopes (Buchardt \& Nielsen 1985) and are supported by a study of fluid inclusions (Jensenius 1987). Buchardt et al. (1985: table 1: samples SKK 31-56) measured high vitrinite reflectance values $\left(R_{R}=2.7-2.9 \%\right)$ in the Upper Cambrian shales from Skelbro 1 and Billegrav 1, which thus have reached the post-mature stage with regard to oil generation. The clay minerals in the shales have been identified in $\mathrm{X}$-ray diffractograms of chemically pretreated samples (Fig. 9) (methodology after Thomsen et al. (1983)). Fig. 11 shows the composition of the clay mineral assemblage, which comprises detrital clay as well as authigenic minerals formed during diagenesis. Two clay mineral assemblages can immediately be distinguished. The first, dominated by illite, is characteristic of the Alum Shale. The second contains a fair amount of chlorite, an upwards decreasing amount of kaolinite, 


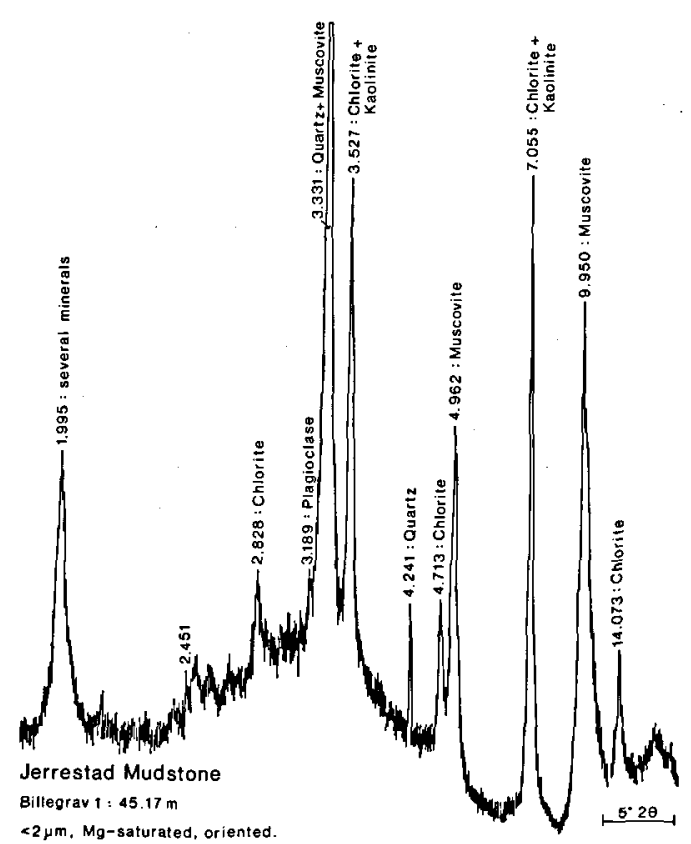

Fig. 9. X-ray diffractogram showing the high degree of crystallinity of the clay minerals as well as the presence of chlorite in the Jerrestad Mudstone. Identification of the clay minerals is supported by additional $\mathrm{Mg}$ - and $\mathrm{K}$-saturated oriented subsamples, glycerolated or heated to $300^{\circ} \mathrm{C}$ and $500^{\circ} \mathrm{C}$.

and less illite than below, and occurs in the Upper Ordovician and lower Silurian (Fig. 11). Armands (1972: fig. 3) reports a bulk mineralogy dominated by illite, quartz and $\mathrm{K}$-feldspar from the Swedish Alum Shale. Bjørlykke (1974b) found likewise that the black Cambrian Alum Shale from the Oslo Region consists of illite, fine-grained quartz and diagenetic feldspar, whereas the Middle Ordovician to Silurian shales contain chlorite in addition to illite. As chlorite is not stable during continental weathering, the presence of detrital chlorite points to a source area where erosion was rapid, probably the basic volcanic and plutonic rocks of the Trondheim Region (Bjørlykke 1974a). Thomsen, Lindgreen \& Wrang (1983) reports the dominance of $2 M_{1}$ muscovite in Upper Cambrian shales from Bornholm, and muscovite + chlorite in Silurian shales from Jutland. In the latter the chlorite is interpreted as diagenetic (Thomsen et al. 1983). Foscolos \& Powell (1979) recorded a relationship between depth, temperature and clay mineral diagenesis, according to which illite and chlorite should be the only stable minerals in the Lower Palaeozoic shales on Bornholm. According to Buchardt \& Nielsen (1985), however, there is no difference in diagenetic regime between the Upper Cambrian and the lowermost Silurian of Bornholm and diagenesis is therefore supposed to have provided a uniform overprint on the detrital clay assemblages. The observed change in the clay mineralogy (Fig. 11) is therefore interpreted as mainly detrital. This is supported by the contemporaneous appearence of chlorite in the Oslo Region (Bjørlykke 1974b) and on Bornholm, which points to the introduction of a new area of provenance, probably within the Caledonides, of increasing importance in the Upper Ordovician.

Weaver (1960) noted a link between the sharpness of the $10 \AA$ illite peak and the degree of diagenesis or low grade metamorphism. He defined a sharpness ratio on basis of the peakheight at $10 \AA$ and $10.5 \AA$. In the present study the position of the peak varies between $9.9 \AA$ and $10.2 \AA$. Accordingly, the sharpness ratio has been calculated as peak-height in the top of the peak and the height $0.5 \AA$ higher. These ratios are listed in Fig. 11, and values of 2.0-2.3 have been calculated. According to Weaver (1960, table 1) this corresponds to deep burial diagenesis grading into incipient metamorphism. Kübler $(1967,1968)$ defined an illite crystallinity index, based on the width of the $10 \AA$ peak at half height. Brazier et al. (1979) proposed a modification in the calculation of the illite crystallinity index, namely that the peak-width values should be measured in 'degrees $2 \theta$ '. Their suggestion is followed here and values of 0.7 have been calculated (Fig. 11).

Both sharpness ratio and crystallinity index were calculated in parallel oriented mounts of the Mg-saturated subsample of the clay fraction. The diffractograms were run slowly and the $10 \AA$ peak is therefore very well defined. Both the sharpness ratio and the crystallinity index lack a systematic variation, which indicates the same degree of diagenesis through the sequence, in agreement with the isotope data of Buchardt \& Nielsen (1985).

Pyrite form penecontemporaneously in finegrained marine sediments through reduction of sulphate from the seawater (Berner 1981). The pyrite content has been assessed through X-ray 


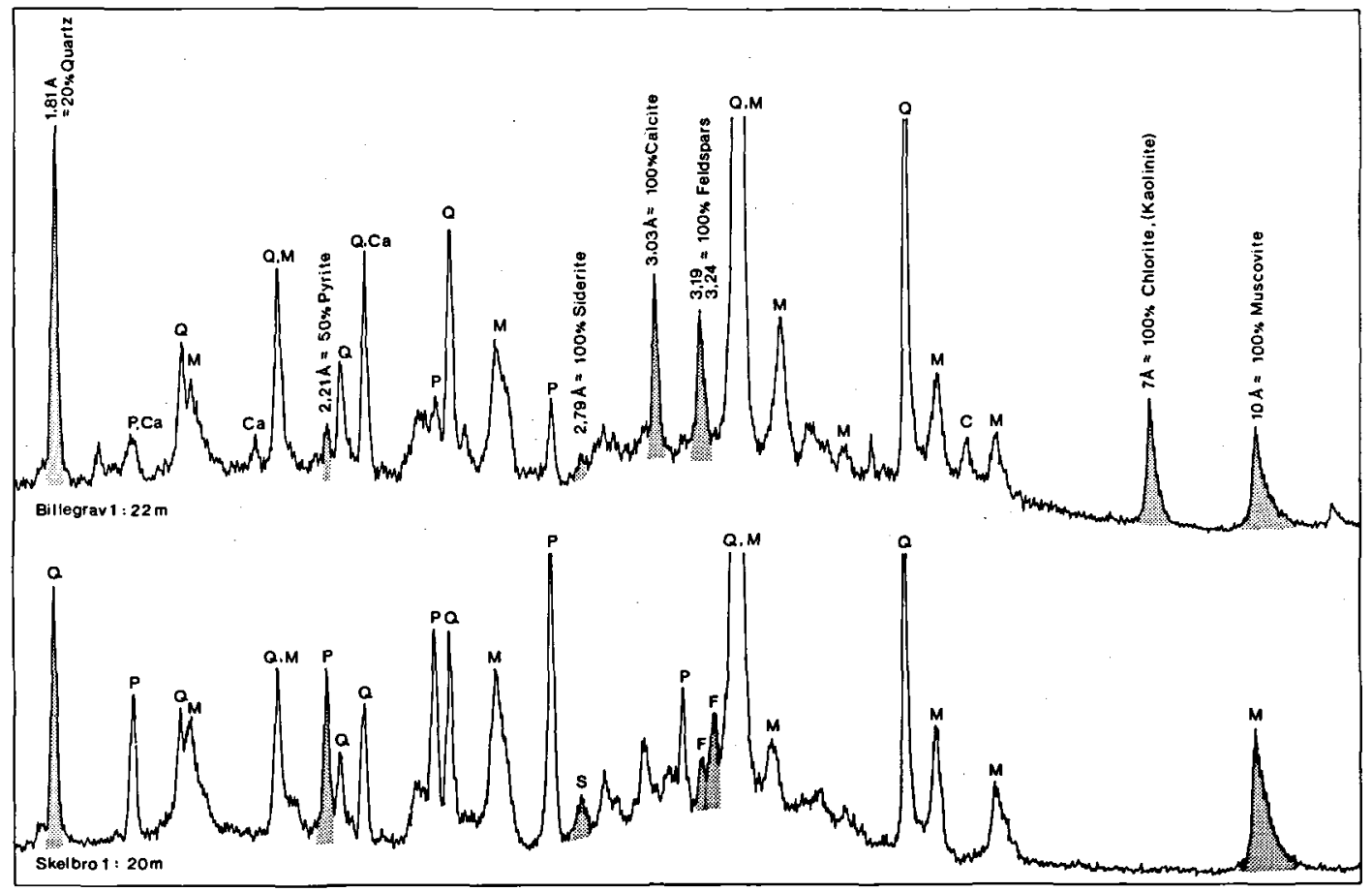

Fig. 10. X-ray diffraction of two bulk samples with random orientation. The shaded peaks have been used for calculation of the relative amounts of the minerals (Fig. 11).

diffraction of powdered bulk samples, and is plotted against the TOC values in Fig. 11. The distributions of TOC and pyrite are roughly symmetrical. A similar pattern is found in the Middle and Upper Cambrian Alum Shale in Southern Sweden (Armands 1972: fig. 3).

\section{Sedimentary sequence}

The sedimentary sequence can be divided into three facies associations. The lower is dominated by black mudshale (Skelbro 1, 37-4 m), the middle is characterized by dark to pale grey mudstone (Billegrav 1, 60-28 m) and the upper is dominated by siltshale (Billegrav 1, 28-2 m). The mudstone association is intermediate between the mudshale and the siltshale associations, though with the greatest similarity to the latter. It should be noted that the Komstad Limestone is intercalated in the sequence of upward coarsening shales which also includes several hiati of long duration.
The mudshale association is distinguished by the high TOC values, the high content of pyrite, the mineralogy, the diagenetic limestone concretions and the irregular distribution of fossils. Subordinate levels of black mudstone are intercalated in the mudshale. The limestone concretions encountered in Skelbro 1 (18-13.5 m) correspond probably to three of the four levels in the Læsa profile shown by C.Poulsen (1923: fig. 2). This correlation is based on the recognition of the Orusia level in the core (Skelbro 1, $20.7 \mathrm{~m}$ ) and on the first occurrence of the wedgeshaped pyrites (Skelbro 1, $18 \mathrm{~m}$ ) which corresponds to the Orusia-Parabolina Zone (C.Poulsen 1923). The mudshale association corresponds to the Lower and Upper Alum Shale. The black organic-rich mudshale is interpreted as an anoxic marine hemipelagite, which accumulated very slowly through settling of mud in an environment lacking current-influence on the sedimentation.

The mudshale association accumulated during the Middle and Late Cambrian and the Early Ordovician. In the Oslo Region the Upper Cambrian clastic sediments are very fine-grained, rich 


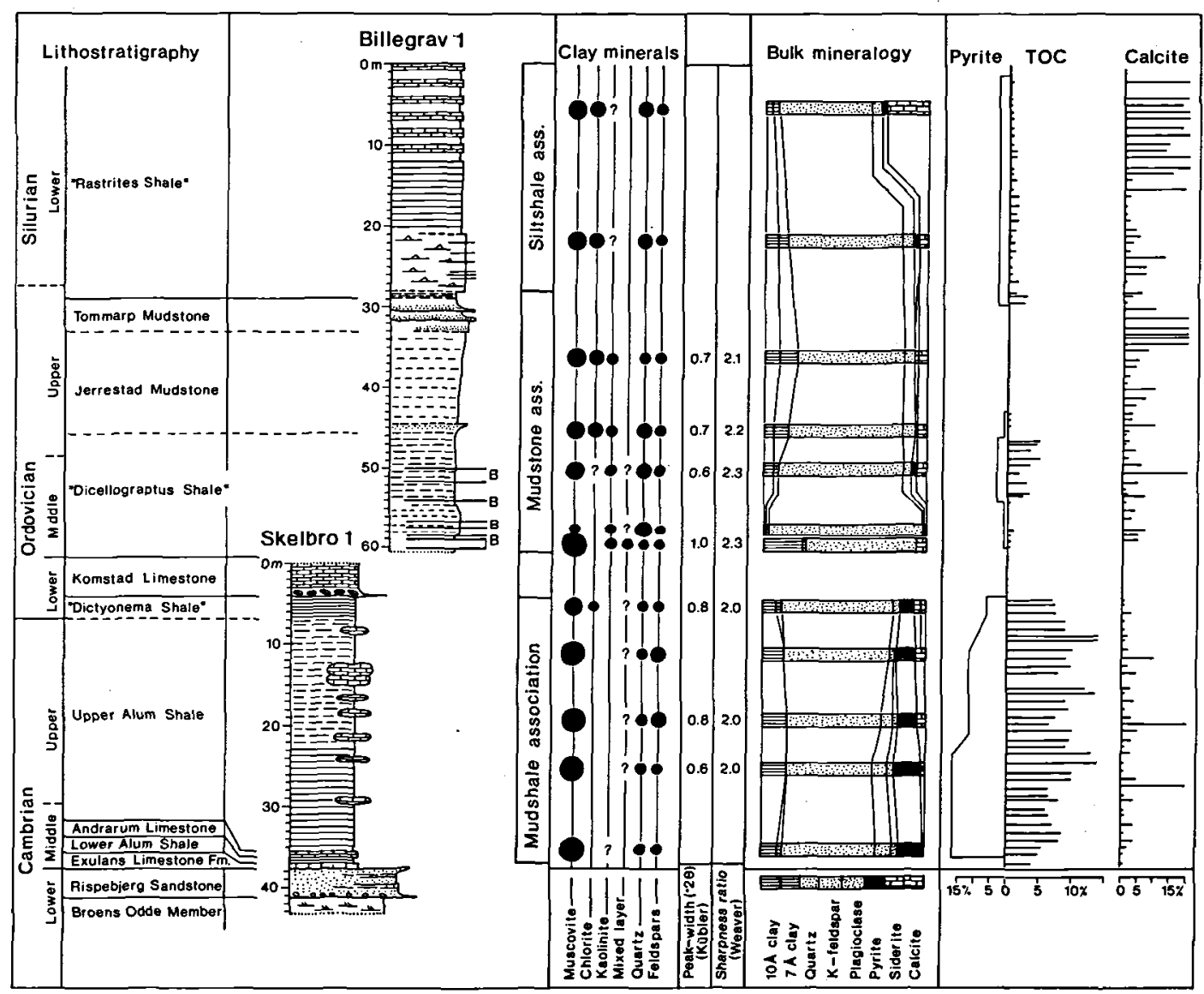

Fig. 11. Mineralogy, TOC and carbonate content within the shale sequence. The clay minerals were identified through XRD of parallel oriented mounts in chemically pretreated samples $<2 \mu \mathrm{m}$ and the size of the black dots is proportional to the height of the peaks in the diffractograms. The bulk mineralogy were calculated from XRD-peak heights in random oriented mounts. TOC and $\mathrm{CaCO}_{3}$ contents were determined by Buchardt et al. (1985). Please note that the mudshale, the mudstone and the siltshale associations possess distinct combinations of sedimentary structures, mineralogy, TOC and carbonate contents.

in TOC and pyrite and deposited through settling from suspension in a relatively deep shelf sea characterized by permanent stagnant conditions (Bjørlykke 1974b). In Sweden alum shales are characteristic of the Middle Cambrian to lowermost Ordovician (Andersson et al. 1985, Thickpenny 1984). A detailed comparison of sedimentary facies and their faunas in Sweden and on Bornholm have not yet been attempted. However, the gross likeness between the areas agrees with the interpretation of the mudshale as a hemipelagite deposited in a relatively deep outer shelf environment in which lateral continuity of the facies is expected.

The mudstone association is distinguished by extensive bioturbation, variable TOC values, small contents of pyrite and a higher proportion of quartz (Figs 2,11). It corresponds to the Dicellograptus Shale, the Jerrestad Formation and the Tommarp Mudstone (cf. Bjerreskov \& Stouge 1985). A minimum of 18 bentonite beds are included in the Dicellograptus Shale. The mudstone association include also black mudstone (Billegrav 1, 54-46 m) and debris flow conglomerates (Billegrav 1, 32-31 m).

Widely different faunas are encountered in the mudstone association. Trace fossils are locally recognizable and are referred to Chondrites (Figs 4B, 7B). A benthic fauna of trilobites and brachiopods is known from the grey mudstone of the Jerrestad Formation (Ravn 1899) and from the Dalmanitina beds (V.Poulsen 1978), The Dicellograptus Shale is characterized by a graptolite fauna (Bjerreskov \& Stouge 1985). 
Due to the bioturbation there is little sedimentary evidence of the depositional processes, but presumably fine-grained density flow deposits alternated with hemipelagic sedimentation. The presence of supposedly detrital chlorite and the relatively high content of quartz indicate a new source of sediment, probably within the $\mathrm{Ca}$ ledonides as discussed by Bjørlykke (1974a).

The mudstone association corresponds to the Middle and Late Ordovician and follows, after a hiatus of several zones, upon the Early Ordovician Komstad Limestone (V.Poulsen 1966, Bjerreskov \& Stouge 1985). The latter is a relatively shallow water deposit with a rich trilobite fauna and can be traced to Sweden, where it is thicker (Nielsen 1985). The boundary between the Komstad Limestone and the Dicellograptus Shale is lacking in the cored sequence because technical difficulties forced a stop to the drilling of Billegrav 1 before the Komstad Limestone was reached. According to Gry (1948) a pyritized conglomerate forms the base of the mudstone sequence. This may be interpreted as a transgressive conglomerate. The Dicellograptus Shale constitutes an upward fining sequence interpreted to pass from normal marine bioturbated mid-shelf silty mud to weakly oxic or anoxic graptolitic outer shelf mud without trace fossils.

A well defined CU sequence is seen in the Upper Ordovician where weakly oxic outer shelf mud with a pelagic fauna of graptolites (upper part of Dicellograptus Shale) is overlain by normal marine shelf mudstone (Jerrestad Fm.) with a fauna of trilobites and brachiopods, capped by debris flow deposits (Tommarp Mudstone). The latter may represent the fill in channels eroded in former shelf deposits. The combination of intraformational mud clasts and fragments of crystalline basement support this interpretation. Contemporaneous shallowing sequences are widely known (Berry \& Boucot 1973, Brenchley \& Newall 1984, Fortey 1984). In the Oslo Region the evidence of a continuous shallowing up to the Ordovician-Silurian boundary is an upward coarsening sequence (Bjørlykke 1974b) with a Hirnantian fauna (Brenchley \& Cullen 1984). The matching Dalmanitina fauna is characteristic of deeper, cold water environments (Brenchley \& Cullen 1984). Nilsson (1979) described sea level fluctuations in the Dalmanitina beds of Scania.
Fortey (1984) estimated that fluctuations in the Ordovician Gondwanaland ice sheet could cause eustatic sea-level changes of $50-100 \mathrm{~m}$. It therefore seems likely that the $\mathrm{CU}$ sequence and the Dalmanitina fauna in the Upper Ordovician on Bornholm reflects the global eustatic fall in sea level caused by the extensive glaciation in Gondwanaland.

The siltshale association is distinguished by a fauna of graptolites, laminated sediments, low TOC values, high contents of quartz and the presence of chlorite and muscovite. The high carbonate content (Billegrav 1, 13-2 m) is diagenetic. The siltshale association corresponds to the lower, non-exposed, part of the Rastrites Shale (Bjerreskov 1975).

The mineral assemblage is strongly dominated by quartz, while chlorite and muscovite are present in almost equal amounts. The chlorite is interpreted as detrital and reflects a source area characterized by rapid erosion (Bjørlykke 1974b).

The siltshale association is interpreted as dominated by density flow deposits with a higher average rate of deposition, which also may explain the slight degree of bioturbation. The lower siltstreaked shale is characterized by top-cut-out sequences and can, accordingly, be interpreted as a proximal facies (middle to outer shelf). The overlying siltshale is characterized by base-and-topcut-out sequences and may therefore be more distal (outer shelf) according to Stow \& Piper (1984).

The lowermost Silurian have a weak upward fining trend from the silt-streaked shale and siltshale (Billegrav 1, 28-0 m) into the grey mudshales exposed along Øleå (Bjerreskov 1975). Brenchley \& Newall (1984) noted, that the rapid basal-Silurian transgression corresponds to a hiatus in many deep water sequences, probably because most sediment was trapped in the continental or shoreface environments. This brief interlude of starvation may explain the thin black mudshale in the lowermost Silurian (Billegrav 1, 31-28 $\mathrm{m}$ ). This interval is a characteristic peak on the gamma-ray logs (Fig. 12). The abrupt upward transition into silt-streaked mudshale reflects thus the switch back to relative high-energy, outer shelf deposits.

Berry \& Wilde (1978: fig. 2) postulated that anoxic environments should be very widespread 


\section{Sømarken 2}

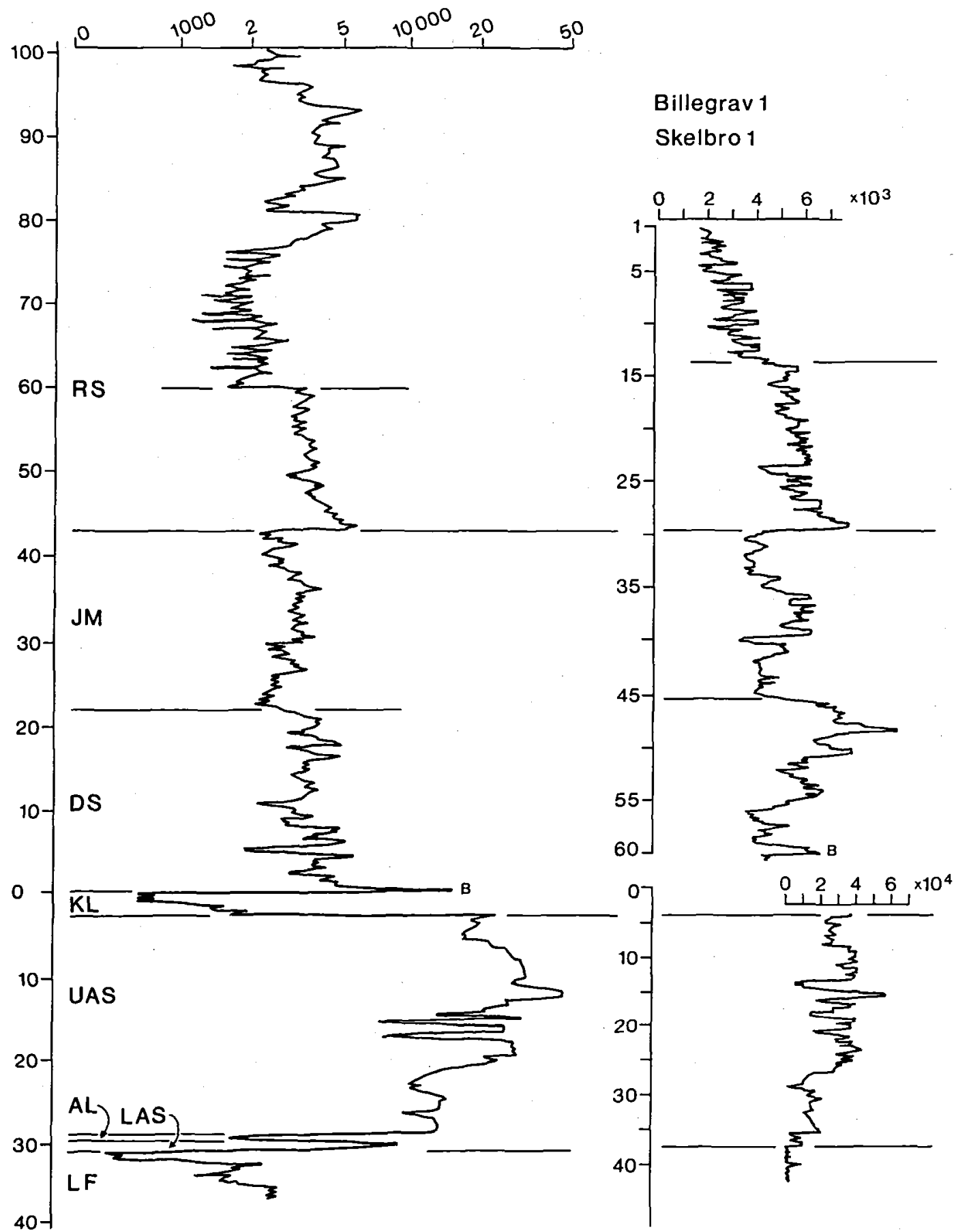

Fig. 12. Correlation of gamma-ray log motifs from three shallow wells located in Fig. 1. Note the similarity in log patterns which indicate lateral continuity of the sedimentary facies. Note also the agreement between the gamma-ray log and the measured TOC values in Skelbro 1 and Billegrav 1. The log in Sømarken 2 was run by Terraqua and the logs from Billegrav 1 and Skelbro 1 were run by A.M.Nielsen and Kurt Klitten, DTH. LF: Læså Fm., LAS: Lower Alum Shale, AL: Andrarum Limestone, UAS: Upper Alum Shale, KL: Komstad Limestone, B: bentonite, DS: Dicellograptus Shale, JM: Jerrestad Mudstone, RS: Rastrites Shale. The lithostratigraphy of Billegrav 1 and Skelbro 1 is also shown in Fig. 11. 
in the Upper Cambrian and Lower Ordovician. Thickpenny \& Leggett (1987) found that black shale facies are especially prominent in the early Upper Cambrian, the latest Llandeilo-Caradoc and the early Llandovery. In the studied sequence anoxic depositional environments were dominant in the Middle Cambrian to Lower Ordovician (Skelbro 1, 37-4 m) in the upper Middle to lower Upper Ordovician (Billegrav 1, 54.5-46 $\mathrm{m}$ ) and possibly in the basal Silurian (Billegrav 1, 29-2 m). The two former are fine-grained, organic-rich, low-energy deposits, while the latter is coarser-grained, contains little organic matter and represents comparatively higher-energy deposits devoid of benthos. Leggett et al. (1981) demonstrated a connection between transgressions and widespread occurrence of the black shale facies and reported minor oscillations between oxic and anoxic environments. The two anoxic or weakly oxic sequences from Billegrav 1 are also interpreted as transgressive, but while the lower of these $(54-46 \mathrm{~m})$ reflects a slow deepening, the upper $(29-2 \mathrm{~m})$ represents a rapid rise in sea level following the Gondwanan deglaciation.

The litho- and biostratigraphy of the CambroSilurian shales has been summarized by V.Poulsen (1966) and Bjerreskov \& Stouge (1985). The present study provides additional data on those parts of the sequence which are not exposed at present. Thus the Upper Alum Shale is found to be $31.5 \mathrm{~m}$ thick in Skelbro 1, while the thickness previously has been estimated to $25,5 \mathrm{~m}$ (V.Poulsen 1966) in the nearby Lasa section. Incomplete exposures have likewise indicated a thickness of about $12 \mathrm{~m}$ for the Upper Ordovician Jerrestad Formation and Dalmanitina beds (V.Poulsen 1978, C.Poulsen \& V.Poulsen 1979) while these units are $16.5 \mathrm{~m}$ thick in Billegrav 1 (46-29.5 m) and $20 \mathrm{~m}$ in Sømarken 2.

The existence of sediments representing the persculptus Zone were known from cuttings from the Bavnegård 1 well near Øleå (Bjerreskov 1975, V.Poulsen 1978). The cores from Billegrav $1(28-1.5 \mathrm{~m})$ provide, however, the first sedimentological details on this sequence of siltstreaked shale from the uppermost Ordovician to the lower most Silurian.

\section{Summary and conclusions}

The Middle Cambrian to lower Silurian of Bornholm is dominated by grey to black shales which range from fine-grained organic-rich black mudshale to grey silt-streaked mudshale. The geological setting implies deposition within an epicontinental sea and the biostratigraphy has shown that the average rate of deposition was low and punctuated by several hiati.

This study has been based on cores through partly unexposed strata and shows that the Upper Alum Shale is $31.5 \mathrm{~m}$ thick and that the Jerrestad Formation plus the Tommarp Mudstone is $16.5 \mathrm{~m}$ thick, thereby exceeding earlier estimates of their thicknesses. A very detailed correlation of gamma-ray log motifs is possible between wells adjacent to Billegrav 1. The correlation indicate uniform thicknesses and lithologies within the sedimentary facies and the gamma-ray log may prove very useful in future studies of the lithostratigraphy.

Five shale facies, a bentonite and a conglomerate sandstone facies are grouped into three facies associations which constitute an upwards coarsening sequence. The lower mudshale association is interpreted as an anoxic hemipelagite which accumulated very slowly. The overlying mudstone association reflects weakly oxic environments and thus an improved ventilation. The succeeding siltshale association is interpreted as dominated by density current deposits in a shelf sea, where the rate of deposition increased and detrital chlorite was introduced due to the onset of the Caledonian orogeny.

The three facies associations recognized here corresponds to previously established lithostratigraphical units. The sedimentary facies of the uppermost Ordovician and lowermost Silurian are documented by cores for the first time, and the Billegrav 1 sequence strenghtens the basis for recognition of eustatic sea-level changes related to the Gondwanaland glaciation in the Ordovician-Silurian boundary of Bornholm.

\section{Acknowledgements}

The Geological Survey of Greenland generously placed its drilling equipment as well as an experienced technical staff at my 
disposal. The work was financed by grants (j.nr. 11-4482) from the Natural Science Research Council and from the Danish Energy Agency (EFP-83, 2251-302). Access to the drill sites was permitted by Fredningsnævnet for Bornholms amts fredningskreds (j.nr. 70/1984) and by Mr. Mogens Koefoed, Billegravgård. The drilling crew comprised J.Boserup, T.Cederberg, A.C.Clausen, A.T.Nielsen, G.K.Pedersen and K.Villadsen. The gamma-ray and resistivity logs were run by A.M.Nielsen and Kurt Klitten, Institute for Applied Geology, DTH.

An earlier draft of this paper was improved by suggestions from M.Bjerreskov and A.T.Nielsen. P.Andersen, O.B.Berthelsen and R.Madsen assisted in the preparation of the manuscript. I direct my best thanks to the abovementioned persons and institutions.

\section{Dansk sammendrag}

To videnskabelige undersøgelsesboringer, Skelbro 1 og Billegrav 1, blev i 1984 udført gennem de palæozoiske skifre på Bornholm. Borearbejdet blev foretaget med materiel og personale fra Grønlands Geologiske Undersøgelse og resulterede i borekerner med en samlet langde på $104 \mathrm{~m}$. Borekernerne repræsenterer et vertikalt snit, som ikke ville kunne sammenstykkes af de eksisterende blotninger, især ikke for lagserien omkring Ordovicium-Silur grænsen. På basis af sedimentære strukturer, mineralogi, indhold af organisk materiale (TOC) og sporfossiler er skifrene inddelt i 6 sedimentære facies, hvortil kommer 18 lag af bentonit (facies 7). Skifrene har traditionelt været tolket som epikontinentale, og den nærvarende undersøgelse illustrerer, at en række, indbyrdes forskellige, aflejringsmiljøer eksisterede. Specielt Alun Skiferen mangler en analogi blandt moderne shelfaflejringer. I forbindelse med borearbejdet måltes gamma-ray logs, og der kan dels påvises karakteristiske logmønstre for hver facies, dels kan der foretages en korrelation til gamma-logs $i$ nærliggende vandboringer. Denne korrelation viser at de enkelte facies har en stor lateral udbredelse og at de er meget ensartede. De sedimentære facies kan samles i tre faciesassociationer domineret af henholdsvis mudderskifre, muddersten og siltskifre. Mudderskiferassociationen omfatter en finkornet, lamineret skifer med et meget stort organisk indhold og med optraden af fossiler $\mathbf{i}$ enkelte niveauer. Den tolkes som hemipelagisk sedimentation under overvejende anoxiske betingelser $o g$ den er dominerende indenfor Alun Skiferen. Mudderstens-associationen omfatter grå skifre med lave TOC indhold, uden lamination men med relativt hyppigt forekommende sporfossiler, Chondrites. Skifrene tolkes som aflejret på den ydre del af shelfen i områder med svag til normal iltholdighed. Mudderstens-associationen er reprasenteret i Dicellograptus Skiferen og i Jerrestad Fm. Disse udgør tilsammen en opad grovende sekvens, som tolkes som en respons på den sen-ordoviciske eustatiske havspejlsænkning i forbindelse med glaciationen i Gondwanaland. Siltskifer-associationen omfatter siltrige skifre med lavt TOC, højt kvartsindhold, tydelig lamination og tidligt silure graptoliter. Siltskifrene tolkes som aflejret af densitetsstrømme som muligvis var stormgenererede. Siltskifer-associationen indeholder formodet detrital chlorit, der tolkes som dannet i forbindelse med den caledoniske orogenese.

Borekernerne fra Skelbro 1 og Billegrav 1 dokumenterer en rakke forskelle i de undersøgte skifres sammensatning og aflejringsbetingelser, og borekernerne rummer samtidig det længste kontinuerte snit, fraregnet overgangen mellem Komstad Kalken og Dicellograptus skiferen, igennem den nedre Kambriske til nedre Silure lagserie på Bornholm.

\section{References}

Andersson, A., Dahlman, B. G. \& Gee, D. G. 1983: Kerogen and uranium resources in the Cambrian alum shales of the Billingen-Falbygden and Närke areas, Sweden. Geol. Fören. Stockh. Förh. 104. 197-209.

Andersson, A., Dahlman, B., Gee, D. G. \& Snäll, S. 1985: The Scandinavian alum shales. Sver. geol. Unders., Ser. $\mathrm{Ca}, 56,50 \mathrm{pp}$.

Armands, G. 1972: Geochemical studies of uranium, molybdenum and vanadium in a Swedish alum shale. Stockholm Contr. Geol. 27, 1-148.

Benton, M. J. \& Gray, D. I. 1981: Lower Silurian distal shelf storm-induced turbidites in the Welsh Borders: Sediments, tool marks and trace fossils. J. geol. Soc. London, 138, 675-694.

Bergström, J. 1982: Scania. In: Bruton, D. L. \& Williams, S. H. (Eds): Field excursion guide. IV Int. Symp. Ordovician System. Paleont. Contr. Univ. Oslo 279, 184-197.

Bergström, J. \& Shaikh, N. A. 1982: Malmer, industriella mineral och bergarter i Malmöhus län. Sver. geol. Unders., Rapporter och meddelanden $\mathrm{nr}$. 31, Uppsala, $82 \mathrm{pp}$.

Bergström, S. M. 1988: Event-stratigraphic significance of Kbentonite beds in the Ordovician of North America and northwestern Europe. Vth Int. Symp. Ordovician System $1988,9$.

Bergström, S. M. \& Nilsson, R. 1974: Age and correlation of the Middle Ordovician bentonites on Bornholm. Bull. geol. Soc. Denmark 23, 27-48.

Berner, R. A. 1981: A new geochemical classification of sedimentary environments. Jour. Sed. Petrology 51, 359-365.

Berry, W. B. N. \& Boucot, A. J. 1973: Glacio-eustatic control of Late Ordovician-Early Silurian platform sedimentation and faunal changes. Bull. Geol. Soc. Am. 84, 275-284.

Berry, W. B. N. \& Wilde, P. 1978: Progressive ventilation of the oceans - an explanation for the distribution of the Lower Palaeozoic black shales. Am. Jour. Sci. 278, 257275.

Bjerreskov, M. 1975: Llandoverian and Wenlockian graptolites from Bornholm. Fossils and Strata, 8, $94 \mathrm{p}$.

Bjerreskov, M. \& Jørgensen, K. Å. 1983: Late Wenlcok graptolite-bearing tuffaceous sandstone from Bornholm, Denmark. Bull. geol. Soc. Denmark 31, 129-149.

Bjerreskov, M. \& Stouge, S. 1985: Field excursions guide, Bornholm, Denmark. 3rd Int. Conf., Graptolite working group, Int. Palaeont. Ass., Copenhagen 1985.

Bjørlykke, K. 1974a: Geochemical and mineralogical influence of Ordovician Island Arcs on epicontinental clastic sedimentation. A study of Lower Palaeozoic sedimentation in the Oslo Region, Norway. Sedimentology 21, 251-272.

Bjørlykke, K. 1974b: Depositional history and geochemical composition of Lower Palaeozoic epicontinental sediments from the Oslo region. Norges geol. Unders. $305,81 \mathrm{pp}$.

Brazier, S., Robinson, D. \& Matthews, S. C. 1979: Studies of illite crystallinity in southwest England. Some preliminary results and their geological setting. N.Jb. Geol. Paläont. Mh. 1979, 11, 641-662.

Brenchley, P. J. \& Cullen, B. 1984: The environmental distribution of associations belonging to the Hirnantia fauna Evidence from North Wales and Norway. In: Bruton, D. L. (Ed.) Aspects of the Ordovician System. Palaeontol. Contrib. Univ. Oslo 295, 113-125.

Brenchley, P. J. \& Newall, G. 1984: Late Ordovician environment changes and their effect on faunas. $I n$ : Bruton, $D$. L. (Ed.) Aspects of the Ordovician System. Palaeont. Contrib. Univ. Oslo 295, 65-79.

Bromley, R. G. \& Ekdale, A. A. 1984: Chondrites: A trace fossil indicator of anoxia in sediments. Science 224, 872874. 
Buchardt, B., Clausen, J. \& Thomsen, E. 1986: Carbon isotope composition of Lower Palaeozoic kerogen: effects of maturation. Org. Chem. 10, 127-134.

Buchardt, B. \& Nielsen, A. T. 1985: Carbon and oxygen isotope composition of Cambro-Silurian limestone and anthraconite from Bornholm: Evidence for deep burial diagenesis. Bull. geol. Soc. Denmark 33, 415-435.

Bøgvad, R. 1946: Om Muligheden for Tilstedeværelsen af Bento- nit paa Bornholm. Meddr dansk Geol. Foren. 11, 47-54.

Bøgvad, R. 1947: Bentonit og Skiferler. Meddr dansk Geol. Foren. 11, 224-225.

Callisen, K. 1914: Tenformede Tungspatkrystaller ("PseudoGaylussit" og "Pseudo-Pirssonit") i Alunskiferen. Meddr. Dansk Geol. Foren. 4, 245-258.

Clausen, C. K. \& Vilhjálmsson, M. 1986: Substrate control of Lower Cambrian trace fossils from Bornholm, Denmark. Palaeogeogr. Palaeoclimatol. Palaeoecol. 56, 51-68.

Dam, G. \& Clemmensen, L. 1988: Neksø Sandstenen fra Nedre Kambrium. VARV, 1988-3, 84-88.

Demaison, G. J. \& Moore, G. T. 1980: Anoxic environments and oil source bed genesis. Am. Assoc. Petrol. Geol. Bull., $64,1179-1209$.

Dott Jr., R. H., Byers, C. W., Fielder, G. W., Stenzel, S. R. \& Winfree, K. E. 1986: Aeolian to marine transition in Cambro-Ordovician cratonic sheet sandstones of the northern Mississippi valley, USA. Sedimentology 33, 345-367.

Ekdale, A. A. 1985: Paleoecology of the marine endobenthos. Palaeogeogr., Palaeoclimatol., Palaeoecol. 50, 63-81.

Fischer, A. G. \& Arthur, M. A. 1977: Secular variations in the pelagic realm. SEPM Spec. Publ. No. 25, 19-50.

Fortey, R. A. 1974: The Ordovician trilobites of Spitsbergen. Norsk Polarinstitutt Skrifter, Nr. 160, 129 p.

Fortey, R. A. 1984: Global earlier Ordovician transgressions and regressions and their biological implications. In: Bruton, D. L. (Ed.) Aspects of the Ordovician System. Palaeontol. Contrib. Univ. Oslo 295, 37-50.

Foscolos, A. E. \& Powell, T. G. 1979: Catagenesis in shales and occurrence of authigenic clays in sandstones, North Sabine H-49 well, Canadian Arctic Islands. Can. J. Earth Sci. 16, 1309-1314.

Frey, M., Teichmüller, M., Teichmüller, R., Mullis, J., Künzi, B., Breitschmid, A., Gruner, U. \& Schwizer, B. 1980: Very low-grade metamorphism in external parts of the Central Alps: Illite crystallinity, coal rank and fluid inclusion data. Eclogae geol. Helv., 73, 173-203.

Funkquist, H. P. A. 1919: Asaphusregionens omfattning i sydöstra Skåne och på Bornholm. Medd. Lunds geol. Fält$k l u b b$, Ser. B, 11.

Gry, H. 1948: Bentoniten i Bornholms ordovicium. Meddr dansk Geol. Foren. 11, 364-386.

Gry, H. 1977: Geologisk kort over Bornholm. VARV ekskrusions- fører nr. 1, Geologi på Bornholm, pp. 4-5.

Hamberg, L. 1988: Tidevands-og stormdominerede lavmarine af- lejringssystemer relateret til en epi-kratonisk trans-gression, Nedre Kambriske Hardeberga Formation, Skåne. Unpublished thesis, University of Copenhagen, $127 \mathrm{p}$.

Hamblin, A. P. \& Walker, R. G. 1979: Storm-dominated shallow marine deposits: The Fernie-Kootenay (Jurassic) transition, southern Rocky Mountains. Can. J. Earth Sci., 16, 1673-1690.

Hansen, K. 1937: Sammenlignende studier over Kambriet i Skåne og på Bornholm. Meddr Dansk geol. Foren., 9 (2), 151-183.

Hansen, K. 1945: The Middle and Upper Cambrian sedimentary rocks of Bornholm. Danm. geol. Unders., Ser. 2, No. $72,81 \mathrm{p}$.

Henningsmoen, G. 1957: The trilobite family Olenidae. Skr. Norske Vid.-Akad. Oslo. I. Mat.-Naturv. KI. 1957, No. 1.

Jensenius, J. 1987: Regional studies of fluid inclusions in Paleo- zoic sediments from southern Scandinavia. Bull. geol. Soc. Denmark, 36, 221-235.

Kaufmann, R. 1933a: Variationsstatistische Untersuchungen über die "Artabwandlung" und "Artumbildung" in der Oberkambrischen Trilobitengattung Olenus Dalm. $A b$ handl. Geol. Paleont. Inst. Univ. Greifswald, 10, 1-54.

Kaufmann, R. 1933b: Die Einstufung der Olenus-Arten von Bornholm. Paleont. Z., 15, 57-63.

Kübler, B. 1967: La cristallinité de l'illite et les zones tout à fait supérieures du métamorphisme. In: Étages Tectoniques. Colloque de Neuchâtel, 105-122. Institut de Géologie de l'Université de Neuchâtel.

Kübler, B. 1968: Evaluation quantitative du métamorphisme par la cristallinité de l'illite. Bull. Centre Rech. Pau S.N.P.A., 2, 385-397.

Leggett, J. K. 1980: British Lower Palaeozoic black shales and their palaeo-oceanographic significance. J. geol. Soc. London, 137, 139-156.

Leggett, J. K., McKerrow, W. S., Cocks, L. R. M. \& Richards, R. B. 1981: Periodicity in the early Paleozoic marine realm. J. Geol. Soc. London 138, 167-176.

Lundegard, P. D. \& Samuels, N. D. 1980: Field classification of fine grained sedimentary rocks. Jour. Sed. Petrology 50, 781-786.

Nelson, C. H. 1982: Modern shallow-water graded sand layers from storm surges, Bering Shelf: a mimic of Bouma sequences and turbidite systems. Jour. Sed. Petrology, 52, 537-542.

Nielsen, A. T. 1985: Stratigraphy, depositional environment and palaeoecology of the Lower Ordovician Komstad Limestone, Southern Scandinavia. Unpublished thesis, University of Copenhagen, $367 \mathrm{p}$.

Nilsson, R. 1979: A boring through the Ordovician-Silurian boundary in western Scania, south Sweden. Sver. Geol. Unders. Ser. C., 766, 18 pp.

Pedersen, G. K. 1985: Thin, fine-grained storm layers in a muddy shelf sequence: an example from the Lower Jurassic in the Stenlille 1 well, Denmark. J. geol. Soc. London $142,357-374$.

Pegrum, R. M. 1984: The extension of the Tornquist Zone in the Norwegian North Sea. Norsk Geol. Tidsskr. 64, 39-68.

Potter, P. E., Maynard, J. B. \& Pryor, W. A. 1980: Sedimentology of Shale. Springer Verlag, New York, Heidelberg, Berlin, 303 p.

Poulsen, C. 1922: Om Dictyograptusskiferen paa Bornholm. Danm. Geol. Unders. IV Rk., Bd. 1, Nr. 16, 25 pp.

Poulsen, C. 1923: Bornholms Olenuslag og deres Fauna. Danm. geol. Unders., Ser. 2, No. 40, 83 p.

Poulsen, C. \& Poulsen, V. 1979: Lag fra Jordens oldtid. In: Nørrevang, A. \& Lundø, J. (Eds) Danmarks Natur 1. Landskabernes opst̊̊en. 3. udg. Politikens Forlag, København, 51-82.

Poulsen, V. 1966: Cambro-Silurian stratigraphy of Bornholm. Meddr. Dansk Geol. Foren. 16, 117-137.

Poulsen, V. 1968: Tretaspis shale at Øleå, Bornholm. Medd. dansk Geol. Foren. 18, 349-350.

Poulsen, V. 1978: Dalmanitina beds (late Ordovician) on Bornholm. Danm. geol. Unders. Arbog 1976, 53-87.

Poulsen, V. 1978b: The Precambrian-Cambrian boundary in parts of Scandinavia and Greenland. Geol. Mag. 115, 131-136.

Ravn, J. P. J. 1899: Trilobit faunaen i den bornholmske Trinucleusskifer. Danm. geol. Unders., Ser. 2, 10.

Rhoads, D. C. \& Morse, J. W. 1971: Evolutionary and ecologic significance of oxygen-deficient marine basins. Lethaia, 4, 413-428.

Savrda, C. E., Bottjer, D. J. \& Gorsline, D. S. 1984: Development of a comprehensive oxygen-deficient marine biofacies model: Evidence from Santa Monica, San Pedro, 
and Santa Barbara Basins, California continental borderland. Am. Assoc. Petrol. Geol. Bull., 68, 1179-1192.

Schlanger, S. O. \& Jenkyns, H. C. 1976: Cretaceous oceanic anoxic events: causes and consequences. Geol. Mijnb. 55, 179-184.

Spears, D. A. 1980: Towards a classification of shales. J. geol. Soc. London 137, 125-129.

Stow, D. A. V. \& Piper, D. J. W. 1984: Deep-water finegrained sediments: facies models. In: D. A. V. Stow \& D. J. W. Piper (eds) Fine-grained sediments: Deep-water processes and facies. Geol. Soc. London, Spec. Publ. 15, 611-646.

Stow, D. A. V. \& Shanmugam, G. 1980: Sequence of structures in fine-grained turbidites: comparison of recent deep-sea and ancient flysch sediments. Sediment. Geol. $25,23-42$.

Surlyk, F. 1980: Denmark. - In: Geology of the European countries, Denmark, Finland, Iceland, Norway, Sweden, 1-50. Dunod. Published in cooperation with the Comité National Francais de Géologie (C. N. F. G.) on the occasion of the 26th International Geological Congress.

Teale, C. T. \& Spears, D. A. 1986: The mineralogy and origin of some Silurian bentonites, Welsh Borderland, U. K. Sedimentology 33, 757-765.

Thickpenny, A. 1984: The sedimentology of the Swedish Alum Shales. In: D. A. V. Stow \& D. J. W. Piper (eds) Finegrained sediments: Deep-water processes and facies. Geol. Soc. London, Spec. Publ. 15, 511-525.
Thickpenny, A. 1987: Palaeo-oceanography and depositional environments of the Scandinavian alum shales: Sedimentological and geochemical evidence. In: J. V. Leggett \& G. G. Zuffa (eds) Marine Clastic Sedimentology. Graham \& Trotman, London, 156-171.

Thickpenny, A. \& Leggett, J. K. 1987: Stratigraphic distribution and palaeo-oceanographic significance of European early Palaeozoic organic-rich sediments. In: Brooks, J. \& Fleet, A. J. (eds) Marine Petroleum Source Rocks. Geol. Soc. London, Spec. Publ. No. 26, 231-247.

Thomsen, E., Lindgreen, H. \& Wrang, P. 1983: Investigation on the source rock potential of Denmark. Geol. Mijnbouw $62,221-239$.

Tissot, B. P. \& Welte, D. H. 1984: Petroleum formation and occurrence. 2nd edit, Springer-Verlag, Berlin Heidelberg, $699 \mathrm{p}$.

Troedsson, G. T. 1932: Några tektoniska och stratigrafiska problem i Skåne. Geol. Fören. Stockh. Förh. 54, 220-226.

Vejbæk, O. V. 1985: Seismic stratigraphy and tectonics of sedimentary basins around Bornholm, southern Baltic. Danm. Geol. Unders. Ser. A, 8, 30 pp.

Weaver, C. E. 1960: Possible uses of clay minerals in search for oil. Bull. Am. Assoc. Petrol. Geol. 44 (9), 1505-1518.

Williams, S. H. \& Rickards, R. B. 1984: Palaeoecology of graptolitic black shales. In: Bruton, D. L. (ed.) Aspects of the Ordovician System. Palaeontol. Contrib. Univ. Oslo $295,159-166$. 